\title{
The hyporheic zone composition of a mining-impacted stream: evidence by multilevel sampling and DGT measurements
}

\author{
Barbara Palumbo-Roe* and Rachel Dearden \\ British Geological Survey, Keyworth Nottingham, NG12 5GG, UK \\ *Corresponding author email: bpal@bgs.ac.uk
}

\begin{abstract}
The importance of the hyporheic zone in influencing stream solute loads and stream ecosystems has been increasingly recognised. The hyporheic zone physicochemical composition of a stream stretch of the Rookhope Burn, a tributary of the River Wear in the North Pennines, UK, affected by historical mining of $\mathrm{Pb}$ ore, was characterised at two contrasting flow and temperature regimes. Vertical element concentration gradients were obtained using multilevel samplers down to a depth of $40 \mathrm{~cm}$ below the water-sediment boundary. Additional in-situ Diffuse Gradients in Thin films (DGT) measurements of surface water and pore water were obtained.

Circumneutral $\mathrm{pH}$ and oxidising conditions characterised the hyporheic zone of the study reach, composed of coarse-textured bed sediments. The surface hyporheic zone (top 15-20 $\mathrm{cm}$ ) was dominated by the chemistry of the overlying water, while interactions with the solid phase were important for some elements in the deeper section of the hyporheic zone.

Manganese was attenuated in the hyporheic zone as shown by SEM analysis of Mn-rich grain coatings from the bed sediment. Fine resolution data obtained through the use of the DGT probe deployed in the sediment at one sampling location, showed localised loss in $\mathrm{Mn}$ and $\mathrm{Zn}$ concentrations at 1.5 to $4.5 \mathrm{~cm}$ below the water-sediment interface. There was clear evidence for hyporheic pore water enrichment in $\mathrm{Pb}$, which was unaffected seasonally, while Zn was greater in the summer sampling. These temporal variations of the hyporheic zone composition warrant consideration when accounting for the contribution of disperse inputs to mining impacted catchments, highlighting the need for hyporheic zone studies taking into account differences in seasons.

The significance of the observed sediment-scale hyporheic processes on the reach-scale geochemical mass balance was estimated by using surface water geochemical loading calculations. Water metal mass balance from four previous sampling events indicated a constant loss of $\mathrm{Mn}$ load, a continuous gain of $\mathrm{Pb}$ load and a more temporally variable loss of $\mathrm{Zn}$ load for a $700 \mathrm{~m}$ stream stretch which included the study site. These results closely agreed with the present observations at the stream bed sediment scale, supporting the importance of hyporheic dynamic solute exchanges in affecting surface water quality for the study stream.
\end{abstract}

\section{Introduction}

Hyporheic water flow is of particular importance to the chemical mass balance of a river catchment, because, as surface water moves through the hyporheic zone and mixes with groundwater in close contact with geochemically and microbially active sediments, enhanced biogeochemical reactions can change solute composition and ultimately affect, through continuous surface water - hyporheic flow exchanges, the solute mass balance at the catchment scale (Harvey and Fuller, 1998; Bencala, 2011). In addition, the importance of the hyporheic zone in influencing freshwater ecology has been increasingly recognised (Malcolm et al., 2009), not only through biogeochemical processes that influence the stream solute loads, but also by providing habitats for benthic biota and regulating $\mathrm{O}_{2}$ and nutrient cycling (Wondzell, 2011).

In the case of rivers with a legacy of contamination, the hyporheic zone can represent both a sink and a source of contaminants (Benner et al., 1995; Fuller and Harvey, 2000; 
Brown et al., 2007; Gandy et al. 2007). In particular, the capacity for contaminant attenuation in the hyporheic zone is of considerable interest from a remediation perspective. Similarly, the legacy of contaminated sediments might represent a long-lasting supply of contaminants to hyporheic porewater, affecting sediment-dwelling organisms and impairing the ecological recovery of the impacted catchment. Hence, understanding the mechanisms of contaminant immobilisation and release in the hyporheic zone and quantifying the net impact on surface water quality is a fundamental prerequisite to remediation and effective management of water quality.

Biogeochemical processes known to affect the hyporheic chemistry of non-conservative elements include acid-base reactions, mineral precipitation/dissolution, sorption and ionexchange, oxidation/reduction, biodegradation and gas dissolution/exsolution (Smith and Jaffé, 1998). Diurnal and seasonal temperature variations are also known to influence solubilities of chemical species and control microbiological activity in river bed sediments (Von Gunten et al., 1991).

Types and rates of biogeochemical reactions are greatly dependent on hydrological controls, corresponding to the rate and direction of water flow (Kimball et al., 1994). Hence, the chemical composition of the hyporheic zone is governed by the chemical reactions that have occurred or are occurring in the sediments and the transport of these solutes within or out of the sediments.

Many studies have recognised the significance of temporal variations in surface water composition affected by varying hydrological conditions. Especially in catchments with dispersed sources of pollution, such as those affected by historical metal mining, inputs of runoff from mining spoil, resuspension of metal contaminated bed sediments and bank erosion can be important during high flow conditions (Gozzard et al. 2011), while groundwater contributions are prominent during base flow conditions. On the other hand, evidence of temporal variability of the hyporheic zone composition is rare and mainly focused on nutrients, temperature and dissolved $\mathrm{O}_{2}$ (DO) (e.g. Malcolm et al., 2009).

The aim of this work was i) to capture the small scale lateral and vertical variations in water quality of the hyporheic zone in a stream stretch of the Rookhope Burn, UK, an upland stream impacted by historical $\mathrm{Pb}$ ore mining during two contrasting sampling episodes and with two sampling methods; ii) to use the geochemical characterisation with changing hydrologic conditions to improve understanding of the processes controlling elemental fluxes to and from the hyporheic zone; iii) to estimate the reach-scale significance of the hyporheic processes observed at local scale by comparing the results to mass balance calculations of contaminant load gains and losses, using previous area-velocity discharge measurements and metal concentrations of surface water in the Rookhope catchment (Banks and Palumbo-Roe, 2010). Given the spatial and temporal heterogeneity of hyporheic exchange (Boulton et al., 1998), there is the potential that small scale investigation might not be representative of the hyporheic zone at the larger scale and it is, therefore, important to investigate the cumulative effects of hyporheic processes. Recent work by Bencala et al. (2011) has highlighted the challenges of understanding the connections of streams to their catchment at scales between hyporheic exchanges and regional river-aquifer interactions. To date there have been only few studies that have estimated the significance of the enhanced chemical reactions in the hyporheic zone at the catchment scale (e.g. Harvey and Fuller, 1998).

\section{Site description}

2.1 Geological setting

The Rookhope catchment is underlain by Dinantian to Silesian interbedded mudstones, siltstones, limestones and shales of the Carboniferous, Yoredale Group. The uppermost 
Stainmore Formation, which cups the catchment, is interbedded with limestone beds typically only a few metres thick, but becoming increasingly common towards the base. The boundary with the Alston Formation is marked by the $15 \mathrm{~m}$ thick Great Limestone member. This is underlain by interbedded deposits $(\sim 30 \mathrm{~m})$ below which, the formation is dominated by thick limestone. Superficial deposits comprise: glacial till below $\sim 370 \mathrm{~m}$ OD; ribbons of alluvial deposits along the course of the River Wear and blanket peat on the higher ground. Artificial deposits are common and include railway embankment fill material and mine waste spoil heaps, some of which are located on the flanks of the River Wear.

The $13 \mathrm{~km}$ long Rookhope Burn runs from headwaters in the NW to the River Wear in the SE through a glacially-incised valley with an elevation drop of $370 \mathrm{~m}$. From the headwaters, the river descends through the Stainmore Formation and into the upper Alston Formation before reaching the study site at an elevation of $320 \mathrm{~m} \mathrm{OD}$, where the river is underlain by alluvium and in turn, interbedded mudstone, siltstone and sandstone deposits. The riverbed undulates and forms cobble-dominated riffles and sand and silt-dominated pools. The stream contributes a discharge of 100 to $2300 \mathrm{~L} / \mathrm{s}$ to the River Wear at Eastgate and responds rapidly to runoff events.

\subsection{Study site}

Figure 1 shows schematic diagrams of the study site detailing the site location and sampling points. The site corresponds to a sampling location (point 23) of a detailed monitoring campaign documenting the metal load distribution in surface water in the catchment between 2007 and 2009 (Banks and Palumbo-Roe, 2010). At this location, the hydrology is influenced by the superficial till and mudstone on the flanks of the valley. These deposits encourage surface run-off, which recharges into the underlying sandstones and dolines to emerge at springs downslope, before entering the Rookhope Burn via minor streams. Recharge that remains below ground percolates downwards through the interbedded deposits until low permeability beds, e.g. mudstones, preclude further progress, causing lateral flow to predominate. Borehole records (British Geological Survey) suggest that above the elevation of the river, the bedrock is dominated by sandstone beds, but below that elevation, interbedded mudstones predominate. Vertical recharge through the sandstone beds is, therefore, likely to be hindered by the interbedded mudstones at river level, causing lateral flows to contribute flow to the hyporheic zone. Inflow to the river from deep groundwater is unlikely given that the horizontal beds of the Alston Formation will act as an impeding barrier to vertical, upward flow. The absence of vertical hydraulic heads measured within standpipes over the top $40 \mathrm{~cm}$ of the hyporheic zone suggests negligible exchange with the aquifer.

The study site is immediately downstream of the washing plant of the Boltsburn $\mathrm{Pb}$ mine (ca. 1860 - 1931), where the mix of rocks and galena ore was washed, broken up and separated. Over the years minerals from other mines were fed in and processing finally stopped in the late 1970s (Bowes and Wall, 1995). On the eastern bank, grassed-over spoil heaps (Fig.1), eroded by the river, as well as a sludge pit, collecting waste pumped from the washing floor, remain.

Visual inspection of the stream on both surveys revealed the extensive presence of blackcoated boulders in the stream bed.

\subsection{Sediment mineralogy and geochemistry}

The stream sediment consisted of poorly sorted, medium to fine sand, gravel and boulders. The mineralogy and metal concentrations of the bed sediment reflect the presence of mine spoil. The mineralogical assemblage of a composite grab sample of sediment from 
the study reach was characterised by dominant quartz ( $\sim 60 \%)$, abundant mica and fluorite ( $15 \%)$, siderite $(\sim 5 \%)$, and minor dolomite, calcite and cerussite $(\sim 1 \%)$, with traces $(<0.5 \%)$ of ankerite, galena, sphalerite and pyrite. Trace elements associated with the mineralisation were significantly enriched with concentrations (size fraction $<150 \mu \mathrm{m}$ ) of $4500 \mathrm{mg} \mathrm{kg}^{-1} \mathrm{Mn}$, $15000 \mathrm{mg} \mathrm{kg}^{-1} \mathrm{~Pb}, 4000 \mathrm{mg} \mathrm{kg}^{-1} \mathrm{~S}$, and $1900 \mathrm{mg} \mathrm{kg}^{-1} \mathrm{Zn}$. Organic matter content, determined as LOI at $405^{\circ} \mathrm{C}$, was low $(<4 \%)$ and soil $\mathrm{pH} 7.3$.

XRD analysis of black-brown coatings scraped-off from the stream boulders revealed a mineral assemblage comprising quartz, goethite, ankerite, fluorite, siderite, mica and calcite. No Mn minerals were unequivocally detected.

\section{Methods}

\subsection{Hyporheic pore water and surface water sampling}

The hyporheic porewater was sampled at four locations along a $12 \mathrm{~m}$ reach using multilevel samplers to a depth of $0.4 \mathrm{~m}$ (Fig. 1). Multilevel samplers were used to monitor the variability of the hyporheic zone at the sediment scale. The multilevel samplers (Rivett et al., 2008) comprised a $12 \mathrm{~mm}$ ID $1200 \mathrm{~mm}$ long, HDPE pipe, fitted at one end with a stainless steel drive-point that assists penetration of the device into sediments. The pipe had two $4 \mathrm{~mm}$ diameter holes at the base to allow the piezometric surface within the hyporheic zone to be monitored. Four discrete $1.6 \mathrm{~mm}$ ID teflon sampling tubes, were attached around the central pipe and were terminated such that ports were located at $10 \mathrm{~cm}$ intervals. Each port was encased in nylon mesh $(45 \mu \mathrm{m})$ screen to prevent sediment blockages. Porewater samples were recovered using a low-flow multichannel peristaltic pump that enabled simultaneous sampling of the four ports at an approximate flow rate of $4 \mathrm{~mL} / \mathrm{min}$; $\mathrm{pH}$ and Eh were measured using a flow-through cell and the Pt electrode Eh measured values were corrected to the Standard Hydrogen Electrode.

Two sampling surveys were undertaken, one in the summer ( $6^{\text {th }}$ July 2010) and one in the autumn (20 $0^{\text {th }}$ October 2010). The hydrological conditions in the catchment were very consistent for at least 10 days before each sampling event. Hydrographs at the Eastgate gauging station [OS grid NY9539] at the base of the Rookhope catchment measured a flow of $0.29 \mathrm{~m}^{3} \mathrm{~s}^{-1}$ during the July sampling event and $0.56 \mathrm{~m}^{3} \mathrm{~s}^{-1}$ during the October event.

The water level in the hyporheic zone was measured relative to the river water level using a Solinst mini dipper placed down the central HDPE tube.

Samples of surface water were collected at each of the four locations. Groundwater was collected from a private well adjacent to the sampling site [NY 94157 42146] for analysis and comparison with the hyporheic pore waters.

\subsection{Chemical analysis}

All water samples were filtered through a $0.45 \mu \mathrm{m}$ Supor $^{\circledR}$ sterile membrane Acrocap ${ }^{\mathrm{TM}}$ filter and collected in sample-rinsed $30 \mathrm{~mL}$ Nalgene ${ }^{\mathrm{TM}}$ high density polyethylene bottles. Alkalinity was determined in the field by titrating $25 \mathrm{~mL}$ of filtered water against $\mathrm{H}_{2} \mathrm{SO}_{4}$, using a bromocresol green indicator solution. Samples for the analysis of major and trace anions, and Non Purgeable Organic C (NPOC) were refrigerated with no further preservation and samples for the analysis of major and trace cations were preserved via acidification with $1 \% \mathrm{HNO}_{3}$ prior to refrigeration. For colorimetric $\mathrm{Fe}$ (II) analysis, $15 \mathrm{~mL}$ of the filtrate was added to $1.5 \mathrm{~mL}$ of a pre-made reagent containing the colour-forming agent 2,2' dipyridyl. Determination of $\mathrm{Cl}, \mathrm{SO}_{4}$ and $\mathrm{F}$ was by ion chromatography (IC) and major and trace elements were determined by inductively-coupled plasma mass spectrometry (ICP-MS). The NPOC content was determined using a Shimadzu TOC-V CPH analyser with associated ASIV auto-sampler. 


\subsection{Quality assurance}

For quality control, field duplicates, field blanks, laboratory replicates and laboratory blanks were included for chemical analysis for every sampling event. Concentrations of major and trace elements determined in procedural blanks were negligible when compared with the reported data. Repeatability of the measurements estimated from the results of duplicate (D) determinations and reported as relative percent difference RPD $=\left(D_{1}\right.$ $\left.D_{2}\right) 100 /\left[\left(D_{1}+D_{2}\right) / 2\right]$ was $<10 \%$ for all elements under investigation for laboratory duplicates. Field duplicates of surface water varied by 1\%, except for $\mathrm{Pb}(28 \%), \mathrm{Fe}(26 \%), \mathrm{Cu}$ and $\mathrm{Zn}$ $(<5 \%)$. However, field duplicates of the hyporheic pore water, sampled less than $15 \mathrm{~min}$ apart, had a variable repeatability for the 4 sampling points and two sampling events, but their RPD was generally much higher (e.g. RPD $\mathrm{Zn}_{5}$ - 50\%; RPDPb 14 - >100\%) than for surface water duplicates. Nagorski and Moore (1999) reported similar low measurement repeatability and speculated that not enough time was allowed between re-sampling to allow replacement water to equilibrate within the hyporheic zone or that the extra amount of water withdrawn for a duplicate sample may have been derived from more distant areas with potentially different chemical signatures. This seems a plausible explanation also in this study. Therefore, only the analysis of the first $30 \mathrm{~mL}$ sample collected were used in the data interpretation and replicate data were not averaged.

\subsection{Diffuse gradients in thin films (DGT) technique principles}

The DGT technique was initially developed to measure bioavailable species in natural waters (Davison and Zhang, 1994; Zhang and Davison, 1995). Later on, the DGT technique was applied to measure fluxes in sediment and soils (Zhang et al, 1995, 1998; Harper et al., 1998). DGT samplers comprise of a Chelex resin gel layer which binds the metals and a diffusion gel layer. The mode of DGT function is extensively described by Zhang et al. (1998). During the deployment in sediments, dissolved metal in the pore water diffuses through the filter and the diffusion gel layer. On contact with the resin layer, the metal is removed from solution by binding to the resin, where its concentration is maintained at zero. This induces a concentration gradient in the diffusion layer between the resin layer and the sediment pore water and causes a steady state flux of metal through the DGT device. The flux (F) of metal diffusing through the diffusion layer $(\Delta \mathrm{g})$ is expressed with Fick's first law of diffusion by equation 1 and the concentration of the labile metal in bulk solution (C) can be calculated using equation 2

(1) $\mathrm{F}=\mathrm{DC} / \Delta \mathrm{g}$,

(2) $\mathrm{C}=\mathrm{M} \Delta \mathrm{g} /(\mathrm{DtA})$,

where $\mathrm{D}$ is the temperature-corrected diffusion coefficient for the free hydrated metal ion in the gel, $\mathrm{M}$ is the mass of metal accumulated in the resin layer, $\mathrm{A}$ is the area of the gel membrane exposed to the bulk solution per unit time (t). In surface water due to fast mixing the concentration at the DGT- water boundary remains constant. In sediments and soils the porewater concentration of solute adjacent to the DGT becomes depleted to an extent depending on the capacity of the solid phase to resupply the porewater and the rate of this supply (Harper et al. 1998). Thus, as the DGT-measured fluxes are affected by both the concentration in the sediment pore water and the resupply from the solid phase, this can be used to derive information on the streambed labile pool by comparing the DGT-derived pore water concentrations to independent pore water determinations using other techniques (Zhang et al., 1995; Harper et al. 1998; Novak et al., 2004). 


\subsection{DGT deployment and analysis}

DGT samplers were used for one of the hyporheic zone sampling locations, a siltdominated pool $1 \mathrm{~m}$ from point 2, during the summer sampling. Standard piston type DGT and sediment probe samplers obtained from DGT Research Ltd., UK, were deployed, respectively, in surface water and in the sediment bed for a period of $24 \mathrm{~h}$ and the initial and final temperature was recorded. The DGT piston unit was attached to a rod by using a fishing line and left suspended in the water column. The DGT piston type was also deployed inside a PVC Standpipe piezometer driven into the stream bed to a depth of $24 \mathrm{~cm}$. The DGT sediment probe protected by a plastic shield was inserted in the sediment using an Al-plate to create a slot in the sediment for the device to be installed and minimise damage. Once inserted to the sediment along its full length $(15 \mathrm{~cm})$, the protector shield was carefully removed leaving the DGT device within the hyporheic zone. After removal, the DGT unit was thoroughly rinsed with MilliQ water and stored in a clean plastic bag. In the laboratory, the gel strip was sectioned horizontally into strips representing increasing $1.5 \mathrm{~cm}$ depth intervals; each strip was then eluted with $2 \mathrm{~mL}$ of $1 \mathrm{M} \mathrm{HNO}_{3}$ solution for $24 \mathrm{~h}$ and the eluent analysed by ICP-MS. Fluxes and concentrations were calculated by equations 1 and 2, using the diffusion coefficients (D) provided by DGT Research Ltd.

\subsection{Mixing ratio calculations}

Mixing between two end-members such as groundwater and surface water in the hyporheic zone can be estimated from a simple mass balance using a conservative element that does not participate in reactions induced by mixing between the two water masses. Given the tracer concentrations of the surface water $\left(\mathrm{C}_{\mathrm{SW}}\right)$ end-member and groundwater $\left(\mathrm{C}_{\mathrm{GW}}\right)$ endmember and the tracer concentration in the hyporheic zone water $\left(\mathrm{C}_{\mathrm{HZ}}\right)$, the proportion $\mathrm{x}$ of groundwater mixed in the hyporheic zone was calculated using:

(3) $\mathrm{C}_{\mathrm{HZ}}=\mathrm{x} \mathrm{C}_{\mathrm{GW}}+(1-\mathrm{x}) \mathrm{C}_{\mathrm{SW}}$.

\subsection{Metal load calculations}

Metal load calculations for a $700 \mathrm{~m}$ stream stretch, upstream and downstream of the study site, were carried out based on data published in Banks and Palumbo-Roe (2010) supplemented by data from Banks et al. (2010), including four sampling events during the period June 2007 and April 2009. Metal loads are calculated by multiplying stream water discharge by metal concentration.

\subsection{SEM Analysis}

Samples of bed sediment grains and pieces of the boulders with black-brown coatings were mounted in an epoxy resin. The resin blocks were then ground using $\mathrm{SiC}$ abrasive discs and polished down to 1- $\mu \mathrm{m}$ using diamond-embedded polishing cloths followed by coating with a thin layer of vacuum evaporated C. The cross section of the interface boundary of the grains and boulders was examined by scanning electron microscopy (SEM) and Energy Dispersive X-ray Micronalysis (EDX). In addition, small pieces of the boulders were removed and mounted on to sample holders and then sputter-coated with Pt metal. This allowed in-situ observation of the surface texture of the black-brown coatings. The above samples were examined in a Philips XL30 SEM using a beam voltage of $20 \mathrm{kV}$. Imaging of Pt coated rough sample surfaces was done using the secondary electron signal, whereas imaging of polished sections was achieved using the back-scatter electron imaging signal. For elemental analysis, an Oxford Instruments INCA-250 EDX microanalysis system was used, fitted with a $\mathrm{Si}(\mathrm{Li})$ detector and ultra-thin entrance window. 


\subsection{Solution speciation and batch-reaction modelling}

Solution speciation and batch-reaction modelling was performed using PHREEQC (Parkhurst and Appelo, 1999) and the WATEQ4f database (Ball and Nordstrom, 1991). Input files to calculate saturation indices of potential solubility controlling phases consisted of the measured total element concentrations in the surface water and pore water solutions.

Stability diagrams for the carbonate minerals cerussite $\mathrm{PbCO}_{3}$ and smithsonite $\mathrm{ZnCO} 3$ and aqueous $\mathrm{Pb}$ and $\mathrm{Zn}$ in equilibrium with those minerals were computed by batch-reaction calculations. Input files contained an excess of cerussite and smithsonite $\left(1 \mathrm{~mol} \mathrm{~L}^{-1}\right)$ as equilibrium phases and the known surface water composition, thus accounting for potential effects of the specific compositional changes and temperature variations of the two sampling events. In order to evaluate the potential for equilibrium of $\mathrm{Pb}$ and $\mathrm{Zn}$ with respect to these phases, the samples were plotted on the stability diagrams (Fig.8). This also allows consideration of the influence of $\mathrm{pH}$ on solubility.

\section{Results}

\subsection{Stream water}

Surface water at the study reach had an alkaline $\mathrm{pH}$ (7.5-8.4). Higher temperature and $\mathrm{pH}$ (8.1-8.4) and greater concentrations of $\mathrm{HCO}_{3}, \mathrm{SO}_{4}, \mathrm{~F}, \mathrm{~B}, \mathrm{Li}$ were observed in July 2010 compared to the October 2010, which in turn was characterised by higher concentrations of NPOC, Mn, Fe, Pb and Zn (Table 1). Together with elemental abundance, the redox state of dissolved Fe also varied, with Fe(II) becoming the dominant species over Fe(III) in surface water sampled in October 2010. The different hydrochemistry of the two sampling events can be explained by a lower base flow contribution and higher overland runoff load in the autumn sampling, characterised by higher flow. Evidence of large temporal variations in hydrochemistry and trace metal concentrations in abandoned mine impacted streams are similarly abundant in literature (e.g. Sandén et al., 1997; Sullivan and Drever, 2001). Both summer and autumn surface waters were supersaturated in goethite $(\mathrm{FeOOH})$ and rhodochrosite $\left(\mathrm{MnCO}_{3}\right)$, but only the summer surface water was supersaturated in calcite and dolomite.

\subsection{Hyporheic pore water chemistry}

Averages and range of physicochemical parameters and elemental concentrations of pore water samples collected in the hyporheic zone in July 2010 and October 2010 are presented in Table 2. Pore water $\mathrm{pH}$ was between 7.3 and 8.4, alkalinity as $\mathrm{HCO}_{3}$ between 90 and 140 $\mathrm{mg} \mathrm{L}^{-1}$, and $\mathrm{SO}_{4}$ concentration $<100 \mathrm{mg} \mathrm{L}^{-1}$. The Eh range was $240-480 \mathrm{mV}$ for July 2010 and $320-400 \mathrm{mV}$ in October 2010. Eh values were also calculated based on the redox $\mathrm{Fe}(\mathrm{II}) / \mathrm{Fe}(\mathrm{III})$ couple. There was no agreement between the measured Eh and that predicted by the $\mathrm{Fe}(\mathrm{II}) / \mathrm{Fe}(\mathrm{III})$ couple $\left(\mathrm{Eh}_{\mathrm{Fe}(\mathrm{II}) / \mathrm{Fe}(\mathrm{III})}\right.$ range $\left.=150-220 \mathrm{mV}\right)$. Nordstrom et al. (1979) calculated redox potentials for the $\mathrm{Fe}(\mathrm{II}) / \mathrm{Fe}(\mathrm{III})$ couple which were very similar to the measured potentials in acid mine waters. In those waters, however, the low $\mathrm{pH}$ and $\mathrm{Fe}$ contents were much more favourable for the use of the $\mathrm{Fe}(\mathrm{II}) / \mathrm{Fe}(\mathrm{III})$ couple in redox calculations than in this study. Hyporheic dissolved organic $C$ was consistently low (1.5- 4.6 $\mathrm{mg} \mathrm{L}^{-1}$ ) in July and higher in October (4.1-19 $\mathrm{mg} \mathrm{L}^{-1}$ ), reflecting the surface water temporal changes. Lead and Zn concentrations were elevated compared to other trace elements (e.g. $\mathrm{Cd}, \mathrm{Co}, \mathrm{Cr}, \mathrm{Cu}$ and $\mathrm{Ni}$ ). Porewater $\mathrm{Pb}$ and $\mathrm{Zn}$ average concentrations from the four monitoring points were $12 \mu \mathrm{g} \mathrm{Pb} \mathrm{L}{ }^{-1}$ (range 2-37 $\mu \mathrm{g} \mathrm{L}^{-1}$ ) and $154 \mu \mathrm{g} \mathrm{Zn} \mathrm{L}{ }^{-1}$ (range 41-392 $\mu \mathrm{g}$ $\mathrm{L}^{-1}$ ) for the July 2010 sampling; $25.5 \mu \mathrm{g} \mathrm{Pb} \mathrm{L}^{-1}$ (range 7-57 $\mu \mathrm{g} \mathrm{L}^{-1}$ ) and $121 \mu \mathrm{g} \mathrm{Zn} \mathrm{L}^{-1}$ (range 39-174 $\mu \mathrm{g} \mathrm{L}^{-1}$ ) for the October 2010 sampling. 
Depth profiles for several constituents of interest are shown in Figures 3 and 4. Hyporheic pore water $\mathrm{pH}$ profiles all shows a slight decrease with depth in the hyporheic zone to a minimum value of 7.3. Two distinct types of dissolved element concentration profiles with depth were noticeable: relatively conservative elements such as B (Fig. 3) and $\mathrm{Li}$ (not shown) among others showed a very small vertical concentration gradient, whereas $\mathrm{Mn}, \mathrm{Fe}, \mathrm{Pb}$ and $\mathrm{Zn}$ concentration profiles were characterised by steeper concentration gradients (Fig. 4). Sulfate behaved conservatively in the hyporheic zone, with concentrations showing little or no difference between surface water and hyporheic water samples, only varying between sampling events (54-92 $\mathrm{mg} \mathrm{L}^{-1}$ in July 2010, 48-54 $\mathrm{mg} \mathrm{L}^{-1}$ in October 2010) (Fig. 3).

On both sampling occasions Fe concentrations in the hyporheic zone were lower than those in surface water and showed a decreasing trend with depth. Hyporheic dissolved Fe concentrations were $<50 \mu \mathrm{g} \mathrm{L}^{-1}$ and Fe(II) species were subordinate to Fe(III) in the July 2010 sampling. In October 2010 total dissolved Fe concentrations were $\sim 500 \mu \mathrm{g} \mathrm{L}^{-1}$ and $\mathrm{Fe}(\mathrm{III})$ was subordinate to $\mathrm{Fe}(\mathrm{II})$ at the majority of sampling locations, with the exception of point 4.

Dissolved Mn in the hyporheic zone was lower than in surface water and decreased considerably with depth in both sampling episodes. Greater differences in concentration between the two sampling events were observed in the shallow hyporheic zone rather than the deeper hyporheic zone, agreeing with the surface water temporal compositional changes, i.e. higher surface water concentrations in October 2010 than in July 2010. Scanning electron microscopy analyses of sediment grains from the bed sediment revealed Mn-enriched coatings (Fig. 5). SEM-EDS measurements were performed at two points of the Mn-rich rim, showing a weight \% average composition of C 8.28\%, O 42.83\%, Mg 0.48\%, Ca 5.07\%, Mn $36.33 \%$, Fe $2.03 \%$, Zn 4.99\%.

Hyporheic dissolved $\mathrm{Pb}$ concentrations were much higher than the surface water dissolved $\mathrm{Pb}$ concentrations and gradually increased with depth in both sampling events. The hyporheic dissolved Pb was higher in October 2010 than in July 2010, agreeing with the surface water temporal compositional change (i.e. higher concentration in October 2010 than in July 2010).

The surface water - hyporheic vertical gradients of dissolved Zn showed distinct opposite trends in the two sampling events. While the dissolved Zn concentrations of the shallow hyporheic zone showed a very small vertical gradient in both July 2010 and October 2010, changing consistently with the surface water (i.e. higher concentration in October 2010 than in July 2010), the dissolved Zn concentrations of the deep hyporheic zone were instead much higher than the surface water dissolved Zn concentrations in July 2010 and considerably lower than the surface water concentrations in October 2010. Furthermore, Zn concentrations in the deep hyporheic zone were lower in October than in July at all sampling points (Fig. 4).

\subsection{Deep groundwater- surface water interaction}

Relatively conservative elements such as B and Li showed very different concentrations in the surface water and deep groundwater samples (Table 1) and were used as tracers to infer the extent of deep groundwater discharge into the hyporheic zone. In accordance with a very narrow vertical concentration gradient (Fig. 3), mixing ratios using equation 3, based on $\mathrm{B}$ and $\mathrm{Li}$ in surface water and groundwater, indicated a small $(<8 \%)$ contribution of deep groundwater to the hyporheic zone.

\subsection{DGT Analysis}


DGT-measured metal concentrations of pore water were obtained with the DGT piston type left floating for $24 \mathrm{~h}$ inside a standpipe piezometer. They were also calculated for the overlying surface water column. The measurements by the DGT piston type for $\mathrm{Pb}$ and $\mathrm{Zn}$ were in good agreement with the corresponding bulk concentrations in solution $(<0.45 \mu \mathrm{m})$ (Fig. 6), with a relative percentage difference (RPD) as follows: RPD Pb (DGT-bulk)Sw $=-12 \%$; $\mathrm{RPD} P \mathrm{~b}_{\text {(DGT-bulk)PW }}=-19 \%$; RPD Zn $\mathrm{n}_{\text {(DGT-bulk)SW }}=+28 \%$; RPD Zn $\mathrm{n}_{\text {(DGT-bulk)PW }}=-12 \%$. In contrast, the DGT- measured Mn and Fe concentrations differed greatly from the bulk concentrations in solution (RPD Fe (DGT-bulk)SW $=-150 \%$; RPD Fe (DGT-bulk)PW $=-140 \%$; RPD $\mathrm{Mn}_{\text {(DGT-bulk)SW }}=45 \%$; RPD Mn (DGT-bulk)PW $=-55 \%$; ). Regardless of the extent of these differences, it is noticeable that, as shown in Figure 6, for the pore water sample at $24 \mathrm{~cm}$ depth, the measurements of Fe, Mn, Pb and Zn obtained by the DGT-piston type were found to be consistently lower than the correspondent bulk concentrations, whereas, for the surface water sample, only Fe and, to a lesser extent, Pb showed lower DGT - concentrations than the bulk concentrations measured in the grasp surface water sample.

Table 3 and Figure 6 show, respectively, the DGT-measured metal fluxes and concentrations of $\mathrm{Fe}, \mathrm{Mn}, \mathrm{Pb}$ and $\mathrm{Zn}$, obtained through the DGT-sediment probe, at a sediment depth sampling resolution of $1.5 \mathrm{~cm}$. Lead fluxes increased with sediment depth. Manganese and Zn profiles show values similar to the surface water column in the top $1.5 \mathrm{~cm}$ depth. After passing through a similar minimum from 1.5 to $4.5 \mathrm{~cm}$ depth, they then increased until $13.5 \mathrm{~cm}$ sediment depth. Iron fluxes (very low) did not show a distinct depth gradient. When compared with bulk element concentrations at 0-10 $\mathrm{cm}$ depth obtained through pore water sampling using multilevel samplers (point 2), DGT - Pb and Zn concentrations were comparable or higher than the bulk concentrations, while DGT - Mn and Fe measurements remained, on a whole, lower (Fig. 6).

\section{Discussion}

\subsection{Flow exchange}

At the reach and the sediment scales, the hyporheic zone is often described as a mosaic of flow path length and depths, with contrasting directions and velocities, due to the complex nature of the substrate (Boulton et al., 1998). Despite this rather complicated potential scenario, the patterns observed at the four sampling points of the study site are fairly consistent.

From the use of B and Li conservative tracers it is evident that mixing of surface water with deep groundwater is insignificant in the hyporheic zone. The suggestion of negligible exchange with the deep aquifer is also consistent with the hydrogeological model (Fig. 2) and the absence of measurable vertical hydraulic heads.

Based on the B and Li concentration profiles, lacking a vertical surface water-hyporheic zone gradient at all sampling points, but significantly different between July and October, it is also suggested that surface water infiltrates downward through the bed sediment. A lack of B and $\mathrm{Li}$ concentration gradients with depth at each sampling episode reflects constant surface water $\mathrm{B}$ and Li concentrations, at least during the period of infiltration.

In order to account for the observed spatial and temporal changes in composition of both conservative and less conservative elements, the working hypothesis is that the downwelling surface water mixes, to various extents, with low-flow or stagnant water. The longer the residence time in the hyporheic zone the greater the interaction between water and sediment. On this basis, the observed vertical solute concentration profiles of non-conservative elements in Fig. 4 suggest i) a "surface hyporheic zone", as defined by Benner et al. (1995), where the hyporheic pore water composition is dominated by surface water and in which the temporal compositional changes largely reflect the surface water compositional changes and 
ii) a distinct "interactive hyporheic zone", where the surface water contribution is subordinate to hydrological and geochemical processes within the sediment in controlling the concentration and distribution of non-conservative elements. The boundary between the surface hyporheic zone and the interactive hyporheic zone was noted around 15- $20 \mathrm{~cm}$ below the water-sediment interface, except for point 4 where it was much closer to the watersediment interface (Figs 3 and 4). This corresponds to an area with relatively finer sediment.

To facilitate the interpretation of the depth profiles by excluding variations due to varying surface water composition between sampling events, the hyporheic pore water concentrations of each metal were normalised to the respective concentrations in the surface water (Fig. 7).

In the following sections the results are discussed in light of possible in-situ geochemical reactions that could control the pore water compositional changes with the aid of geochemical equilibrium models. Although the importance of kinetic reactions in lowtemperature geochemical processes is recognised, comparing the modelling results assuming thermodynamic equilibrium with the measured concentrations can help to highlight the kinetic controls and contribute to understanding a natural system which is often inherently too complex to be modelled.

\subsection{Surface hyporheic zone}

\subsubsection{Iron and manganese}

The hyporheic pore water was significantly poorer in Mn and Fe compared to surface water, showing decreasing concentration trends with depth. This can be attributed to attenuation along the infiltration pathway rather than dilution, based on the following evidence.

Iron attenuation through ferric hydroxide precipitation is suggested by saturation indices indicating goethite as supersaturated in the pore water and corroborated by the presence of goethite detected by XRD in the sediment.

Saturation indices also indicate rhodocrosite $\left(\mathrm{MnCO}_{3}\right)$ as supersaturated in the pore water. Scanning Electron Microscopy (SEM) revealed the Mn-rich composition of black coatings (dominated by Mn (hydr)oxides) on sediment grains and cobbles in the streambed, supporting the attenuation of surface water Mn through precipitation in the surface hyporheic zone. Similarly, Harvey and Fuller (1998) suggested that the microbial Mn oxidation coupled with hydrologic exchange of stream water with the hyporheic water dominates the downstream attenuation of $\mathrm{Mn}$ in the perennial reach of Pinal Creek, AZ, impacted by $\mathrm{Cu}$ mining activities. Iron-Mn coatings on stream alluvium have been observed in many streams (Buckley, 1989; Filipek et al., 1981; Shope et al., 2006). As shown in the SEM analysis (Fig.5), the Mn-rich coatings contain highly active ecosystems, with a diverse assemblage of photosynthetic organisms (diatoms, phytoflagellates and filamentous algae), in a gangue of detrital and authigenic mineral phases. Microbial activity tends to increase the $\mathrm{pH}$ and the redox potential near the rock surface by removing $\mathrm{CO}_{2}$ and releasing $\mathrm{O}_{2}$ (Carpenter and Hayes, 1978) and is believed to mediate the precipitation of Mn and Fe (hydr)oxides (Tebo et al., 2005). However, it is known that these $\mathrm{pH}$ and Eh changes induced by microbial activities are often localised to the cell-surface microenvironment and they may not be detectable at the scale of the whole solution. On this basis, even if equilibrium solution computations for the hyporheic pore water composition indicate the stability of $\mathrm{MnCO}_{3}$ over any $\mathrm{Mn}$ (hydr)oxides, the presence of the latter, mediated by microbial activity, cannot be discounted. The occurrence of Mn (hydr)oxides is indeed suggested by the SEM-EDX data. 


\subsubsection{Zinc and lead}

It is well known that Fe and Mn (hydr)oxides can accumulate a wide range of trace elements. Zinc was observed in abundances as great as $5 \%$ in the Mn-rich coatings, while $\mathrm{Pb}$ was not detectable. This observation is consistent with the observed vertical metal patterns in the surface hyporheic zone. The decrease in pore water Mn and Fe is accompanied by a slight decrease in $\mathrm{Zn}$, but not $\mathrm{Pb}$, suggesting that $\mathrm{Zn}$ attenuation in the shallow sediment of the Rookhope Burn took place via co-precipitation or sorption on Mn oxy-hydroxides. The process is either negligible or masked by other processes for $\mathrm{Pb}$. In fact, with respect to $\mathrm{Pb}$, hyporheic concentrations were much higher than the surface water dissolved $\mathrm{Pb}$ concentrations and gradually increased with depth in both sampling events. From the data in Tables 1 and 2 it is evident that the concentrations of dissolved $\mathrm{Pb}$ in the stream water or deep groundwater could not directly produce the enrichment observed in the shallow hyporheic zone. The bed sediment contains around $1.5 \mathrm{wt} \% \mathrm{~Pb}$ and exerts a greater control on hyporheic pore water $\mathrm{Pb}$ than on other trace metal. This control is enhanced in the deeper interactive hyporheic zone and is discussed in the following paragraph.

\subsection{Interactive hyporheic zone}

\subsubsection{Iron and manganese}

The decreasing trend of Fe and especially Mn concentrations with depth extends to the deep hyporheic zone.

In contrast to other studies (Von Gunten et al., 1991; Benner et al, 1995) and consistent with redox measurements (Table 2), the present data indicate the lack of reductive dissolution of Mn (hydr)oxides and hence an increase in dissolved Mn in the deep hyporheic zone. The consequent process of release of trace metals bound to the oxides is, therefore, deemed insignificant. Prevailing oxidising conditions, as those observed in the hyporheic zone of the study reach, are not uncommon for bed sediments in upland reaches, where surface waterhyporheic zone exchanges are maximised due to sediment coarser texture and hence higher permeability, compared to lowland rivers. The studied bed sediments were indeed relatively poor in clays and organic matter, which are both known to favour the establishment of reducing conditions in saturated soil and sediment systems, respectively limiting the $\mathrm{O}_{2}$ diffusion and consuming the dissolved oxygen by organic matter decomposition.

\subsubsection{Zinc and lead}

Hyporheic zone $\mathrm{Zn}$ and $\mathrm{Pb}$ gradients did not always agree with the observed decreasing vertical trends of $\mathrm{Mn}$ and $\mathrm{Fe}$, as would have been expected considering their strong affinity for Fe and Mn oxides. These differences, which became more evident in the interactive hyporheic zone, suggest a greater role of the bed sediments in supplying $\mathrm{Pb}$ and $\mathrm{Zn}$ to the hyporheic zone pore water.

The Zn concentration pattern with depth varied with the time of sampling. Interactive hyporheic zone Zn concentrations were lower in October than earlier in the summer (Fig. 4) and significantly enriched compared to the surface water in the summer, while depleted in the autumn sampling.

Dissolved $\mathrm{Zn}$ is not controlled by solubility with its respective hydroxide, carbonate (Fig.8) or sulfate minerals, as the samples were calculated to be undersaturated with respect to various sulfate, carbonate, or hydroxide phase included in WATEQ4F (Ball and Nordstrom, 1991). This is not uncommon. Zinc cations released during the weathering of the primary ore mineral sphalerite ( $\mathrm{ZnS}$ ) can be sorbed on organic matter, Fe and $\mathrm{Mn}$ (hydr)oxides and clay minerals, can precipitate with other solute species like Si to form Znrich phyllosilicates (Van Damme et al., 2010) or substitute for Ca, Mn and Fe in carbonate 
minerals (Cravotta, 2008). The reversible nature of these mechanisms, especially sorption/desorption equilibrium induced by changes in $\mathrm{pH}$ and temperature, has been recognised as being responsible for observed large diurnal $\mathrm{Zn}$ cycles in neutral to alkaline streams (Nimick et al., 2011). For the study pore waters small differences in $\mathrm{pH}$ between the two sampling occasions and lack of correlation between solution $\mathrm{pH}$ changes and enrichment/depletion Zn concentration patterns suggest a negligible control of $\mathrm{pH}$ on dissolution or desorption. Similarly, lack of compositional/availability changes of important binding phases such as $\mathrm{Mn}$ and Fe (hydr)oxides (as evidenced by similar decreasing pore water $\mathrm{Mn}$ and Fe profiles and constant oxidising conditions) do not provide a plausible explanation for the interactive hyporheic zone $\mathrm{Zn}$ variations characterising the two sampling events. Constant sulfate vertical profiles were also evidence for a lack of metal attenuation by significant sulfide formation.

The parameter that can plausibly explain these Zn fluctuations is the temperature variation combined with the flow rate change between the July and October sampling. Enhanced sulfide weathering rates at high temperatures due to temperature-dependent microbial activity affecting biotic sulfide oxidation are expected (Strömberg and Banwart, 1999). This mechanism could explain the hyporheic pore water $\mathrm{Zn}$ enrichment in the summer sampling event, even if the sulfate enrichment was less obvious (possibly reflecting an additional control mechanism on dissolved sulfate). The high residence time and low flow of water in the interactive hyporheic zone during the summer sampling can favour the accumulation of $\mathrm{Zn}$ in solution. A slower rate of sulfide mineral oxidation at cold temperatures and a relatively more rapid flow in the autumn sampling could result in the observed $\mathrm{Zn}$ depletion in the pore water of the interactive hyporheic zone. The pore water $\mathrm{Zn}$ composition is then controlled by a balance between release into solution and loss by transport. An alternative explanation to account for the fluctuations in $\mathrm{Zn}$ pore water concentration in the interactive hyporheic zone might be found in the large diurnal variations, which have been observed especially for $\mathrm{Zn}$, but not for $\mathrm{Pb}$, in similar mining-impacted alkaline streams (Shope et al., 2006; Nimick et al., 2011; Frau et al., 2012). These temporal variations in surface water chemistry can complicate the comparison with the hyporheic zone, since the initial $\mathrm{Zn}$ concentration of surface water infiltrating in the bed sediment might have been different from the one at the time of sampling. To follow this hypothesis and derive the travel time of the infiltrating water it would be necessary to monitor more frequently over a period of a week or longer to capture the surface water temporal chemical variations and the hyporheic zone response.

Similarly to the surface hyporheic zone, elevated concentrations of $\mathrm{Pb}$ observed in the hyporheic pore waters, as compared to the associated groundwater and surface waters, provides strong evidence of the sediment being a source of $\mathrm{Pb}$ in the study reach. The hyporheic pore water $\mathrm{Pb}$ profile showed increasing concentrations with depth (up to $~ 20$-fold increase). The saturation indices became closer to saturation with respect to cerussite $\left(\mathrm{PbCO}_{3}\right)$ without reaching saturation ( $\left.\mathrm{SI}_{\max }-0.5\right)$, suggesting on-going dissolution of cerussite. Cerussite was identified by mineralogical analysis. The reasons for the increasing hyporehic dissolved $\mathrm{Pb}$ with depth, already observed in the shallow hyporheic zone, are discussed below. The decreasing rate of infiltrating surface water (low in $\mathrm{Pb}$ ) with depth could account for the observed trend, by decreasing dilution and enhancing residence time. Likewise, the abundance of cerussite through the sediment depth might control the pore water composition by constraining the supply of dissolved $\mathrm{Pb}$ and thus accounting for the change in hyporheic pore water $\mathrm{Pb}$ with depth. These two factors cannot be distinguished with the present data, without knowing the distribution of cerussite throughout the sediment depth. The influence of $\mathrm{pH}$ on mineral dissolution or desorption, due to an observed decrease in $\mathrm{pH}$ 
(minimum value of 7.3) with depth, seems to be negligible considering the mineral stability of cerussite (Fig. 7).

Lead enrichments with respect to the associated surface water in July and October were consistent (Fig. 6). Different temperatures and flow conditions, factors responsible for the temporal variation in Zn concentrations of the interactive hyporheic zone, exert less influence on $\mathrm{Pb}$ concentrations. Cerussite, the main mineral phase controlling $\mathrm{Pb}$ in solution, in fact, increases its solubility as temperature decreases. Moreover, less sensitivity to the flow rate causing depletion is expected as a result of the relatively large abundance of cerussite in the Rookhope Burn sediment. These findings confirm previous synoptic data of the hyporheic zone $\mathrm{Pb}$ composition in the Rookhope catchment and complement them with temporal data and depth concentration profiles (Palumbo-Roe et al., 2012).

\subsection{DGT data analysis}

In this study the two types of DGT device (DGT piston type immersed in surface water /pore water solution and DGT sediment probe deployed directly in the sediment) could provide useful information on the bioavailable pool of metals in solution (Zhang and Davison, 1995) and the labile pool of metals in the solid phase (Harper et al., 1998).

A good agreement was found between measurements of $\mathrm{Pb}$ and $\mathrm{Zn}$ using the DGT piston type and the bulk concentrations, for both surface water and the porewater collected in the standpipe piezometer, while DGT and bulk measurements for Mn and Fe agreed less well. A systematic negative difference between DGT-measurements (lower) and bulk concentrations of the pore water was found, suggesting a bioavailable fraction lower than the dissolved $(<0.45 \mu \mathrm{m})$ metal concentrations in the pore water. In surface water this was noticeable only for Fe, suggesting that the $<0.45 \mathrm{um}$ fraction may have contained Fe in colloidal form along with the truly dissolved form. The DGT measurement could give a better measure of biologically available metals in the porewater for freshwater and benthic organisms.

Many DGT measurements have been carried out in soils or fine-grained sediments dominated by diffusion and where solute velocities are low (mm per day) (Søndergaard et al, 2008). To the authors' knowledge DGT devices have not been deployed before in highly permeable streambeds, such as the study sediments. The conditions at the time of deployment were of very shallow water $(\sim \mathrm{cm})$ and very low flow conditions, which might imply a limited role of advective flow.

The DGT-measured concentrations of $\mathrm{Pb}$ and $\mathrm{Zn}$, obtained through the DGT-sediment probe, at a sediment depth sampling resolution of $1.5 \mathrm{~cm}$, were generally higher than bulk element concentrations obtained through pore water sampling using multilevel samplers (point 2), while Mn and Fe DGT-measurements remained lower than the multilevel sampler concentrations. It is difficult to establish with confidence without further sampling and analysis, whether these differences between DGT and multilevel measurements reflect the spatial variability between the different sampling locations or the capacity of the sediment to resupply the porewater with metals. The latter option would imply that the $\mathrm{Zn}$ and $\mathrm{Pb}$ concentrations in the pore water are well buffered and receiving a constant supply from the sediment, while there is a poor dynamic supply of Fe and Mn from the solid phase.

The use of the DGT sediment probe revealed a localised minimum of Mn and Zn concentrations immediately below the water-sediment interface, further evidence of the observed Mn and Zn attenuation through precipitation in Mn-rich coatings. The use of the DGT probe allowed clearly localising this process at a resolution that could not be achieved with the multilevel pore water sampler. 


\subsection{Significance of the hyporheic zone reactions at the catchment scale}

Comparison of metal loads upstream and downstream of the study site allows the quantification of the amount of the metal which is lost through natural attenuation or gained through visible or dispersed inputs to the stream stretch (Kimball et al., 2002). For the $700 \mathrm{~m}$ long reach, a constant loss of $\mathrm{Mn}$ and a more variable loss of $\mathrm{Zn}$ load in the four sampling seasons were observed (Table 4). Differences in Pb load, where measurable, indicated a contribution to the $\mathrm{Pb}$ load. The influence of tributaries was negligible in terms of metal load contribution and, therefore, the difference between inflows and outflows was attributable to the interaction between the stream and the hyporheic zone. The data in Table 4 are in close agreement with the observations in the study hyporheic zone, supporting the role of the hyporheic zone in the mass balance at greater scale than the sediment scale of the observations.

\subsection{WFD implications}

The scale of environmental problems associated with abandoned non-coal mines throughout England and Wales has been reviewed recently (Mayes et al. 2010), highlighting the significance of point source mine water discharges in causing failures of environmental quality standards (EQS) for metals, set by the EU Water Framework Directive (WFD), in many rivers and streams linked to abandoned mines. Besides these point sources, the extent and impact of mining-related diffuse pollution on failing to achieve the aims of the WFD in these rivers and streams is largely unknown. This information is critical in effective remediation programmes, as diffuse pollution represented by the legacy of contaminated sediments, mine spoil and contaminated groundwater inflows could mean that the chemical and ecological recovery might not be achieved even after the mines are remediated at source.

This study highlights that despite the fact the surface water has relatively low concentrations of dissolved $\mathrm{Pb}$, the enhanced $\mathrm{Pb}$ concentration in the hyporheic zone in the study stream stretch can have an adverse impact on the riparian biota, confirming the findings in Palumbo-Roe et al. (2012). The characterisation of the hyporheic zone, taken with water chemical mass balance, indicates that natural attenuation processes are important for Mn. Whilst, the observed temporal variability in hyporheic pore water Zn composition has important implications because the natural attenuation capacity of a stream is of significant interest from the remediation prospective as long as the attenuation capacity of the stream is stable and expected.

\section{Conclusions}

The data support the following conclusions:

- Oxidising conditions, favoured by permeable organic-poor gravel-sand sediments, prevail in the study hyporheic zone of the Rookhope Burn in both summer and autumn sampling events.

- Downwelling surface water mixes, to various extents, with low-flow or stagnant water, while mixing of surface water with deep groundwater is insignificant.

- Significant interaction between solutes and the hyporheic sediments influenced by solute residence time controls the hyporheic pore water composition. Dissolved $\mathrm{Mn}$ in the hyporheic pore water is attenuated via precipitation within the stream bed sediment. Hyporheic pore water dissolved $\mathrm{Pb}$ results mostly from the sediments. Dissolved $\mathrm{Zn}$ in the hyporheic pore water, in contrast to $\mathrm{Mn}$ and $\mathrm{Pb}$, shows more pronounced changes during the two sampling events, with much greater concentrations in the summer, probably induced by enhanced sulfide weathering rates at high temperatures and accumulation in solution due to high residence time 
characterising the summer sampling period, while it is then lost by flushing out during the colder and higher flow sampling conditions in October.

- It has been show in this study that reach $\mathrm{Pb}$ concentrations are consistently higher in the hyporheic porewater than in surface water and that the hyporheic zone represents an important diffuse source of $\mathrm{Pb}$ contamination to the stream, due to the widespread contamination of $\mathrm{Pb}$-rich sediments in the study catchment, subject to centuries of $\mathrm{Pb}$ ore mining. Despite the fact that the surface water has relatively low concentrations of dissolved $\mathrm{Pb}$, the enhanced $\mathrm{Pb}$ concentration in the hyporheic zone can have an adverse impact on the riparian biota.

- The DGT deployment in a silty-dominated pool of the studied Rookhope stream stretch has demonstrated that it is possible to get a very detailed characterisation of river bed sediment pore waters with the potential to average well documented diurnal variations in these types of streams. More research is needed to explore the DGT potential to calculate contaminant fluxes from the stream sediments of these upland catchments, composed of highly permeable sands and gravel.

- The observations at the stream sediment bed scale proved to be in good agreement with previous mass balance calculations indicating net Mn load loss, mostly net Zn load loss and net $\mathrm{Pb}$ load gains in the Rookhope Burn surface water along a $700 \mathrm{~m}$ stream stretch including the study location, demonstrating the importance of hyporheic processes on the Rookhope Burn catchment scale geochemical mass balance.

- The study suggests that the hyporheic zone of abandoned mine catchments can act as a long term source of metals to rivers, thereby potentially diminishing the short to medium term benefits delivered by point source (e.g. mine water discharges) remediation. These findings have important implications in terms of the EU Water Framework Directive (WFD) implementation and river basin managements in many parts of UK, Europe and equally worldwide, in areas affected by the legacy of metal mining. These polluting sources can pose considerable barriers to compliance with the demands of the WFD. The observed temporal variability in the natural attenuation capacity of a stream, as suggested by the variable hyporheic Zn composition, has important implications for remediation. Further research should focus on more frequent monitoring to improve knowledge of the hyporheic zone processes and the links between concentrations and transport rates.

\section{Acknowledgments}

This work was funded by the Natural Environment Research Council (NERC). The authors are grateful to Rosalind Preston for assistance during sample collection and to the landowner adjacent to the study site for access for sampling. The authors would like to thank colleagues in the BGS laboratories for chemical and mineralogical analysis, in particular Simon Chenery, Chris Milne and Doris Wagner, and Humphrey Wallis for assistance during the development of the hyporheic zone sampling equipment. Martin Roe is thanked for the SEM analysis. The paper is published with the permission of the Executive Director of the British Geological Survey (NERC).

\section{References}

Ball, J.W., Nordstrom, D.K., 1991. User's manual for WATEQ4F, with revised thermodynamic data base and test cases for calculating speciation of major, trace, and redox elements in natural waters: U.S. Geol. Surv. Open-File Rep. 91-183. 
Banks, V.J, Palumbo-Roe, B., 2010. Synoptic monitoring as an approach to discriminating between point and diffuse source contributions to zinc loads in mining impacted catchments. J. Environ. Monitor. 12,1684-1698.

Banks, V., Palumbo-Roe, B., Wood, P.J., Chenery, S.R., Reid, E., 2010. Catchment-scale assessments of the effects of abandoned metal mines on groundwater quality and stream ecology. In: 8th BLRS Conf. 2010 : Restoration and Recovery : Regenerating Land and Communities, South Wales, 7-9 Sept 2010.

Bencala, K.E., 2011. Stream-Groundwater Interactions. In: Peter, W. (Ed.), Treatise on Water Science. Elsevier, Oxford, 537-546.

Bencala, K.E., Gooseff, M.N., Kimball, B.A., 2011. Rethinking hyporheic flow and transient storage to advance understanding of stream-catchment connections. Water Resour. Res. 47, W0OH03.

Benner, S.G., Smart, E.W., Moore, J.N., 1995. Metal Behavior during Surface-Groundwater Interaction, Silver Bow Creek, Montana. Environ. Sci Technol. 29, 1789-1795.

Boulton, A.J., Findlay, S., Marmonier, P., Stanley, E.H., Valett, H.M., 1998. The functional significance of the hyporheic zone in streams and rivers. Ann. Rev. Ecol. Syst. 29, 59-81.

Bowes, P., Wall, T., 1995. Rookhope’s landscape legacies. North Pennines Heritage Trust, Alston, Cumbria, UK.

Brown, B.V., Valett, H.M., Schreiber, M.E., 2007. Arsenic transport in groundwater, surface water, and the hyporheic zone of a mine-influenced stream-aquifer system. Water Resour. Res. 43, W11404.

Buckley, A., 1989. An electron microprobe investigation of the chemistry of ferromanganese coatings on freshwater sediments. Geochim. Cosmochim. Acta 53, 115-124.

Carpenter, R.H., Hayes, W.B., 1978. Precipitation of iron, manganese, zinc, and copper on clean, ceramic surfaces in a stream draining a polymetallic sulphide deposit. J. Geochem. Explor. 9, 31-37.

Cravotta III, C.A., 2008. Dissolved metals and associated constituents in abandoned coalmine discharges, Pennsylvania, USA. Part 2: Geochemical controls on constituent concentrations, Appl. Geochem. 23, 203-226.

Davison, W., Zhang, H., 1994. In situ speciation measurements of trace components in natural waters using thin-film gels. Nature 367, 546-548.

Filipek, L.H., Chao, T.T., Carpenter, R.H., 1981. Factors affecting the partitioning of Cu, Zn and $\mathrm{Pb}$ in boulder coatings and stream sediments in the vicinity of a polymetallic sulfide deposit. Chem. Geol. 33, 1-4, 45-64.

Frau, F., Cidu, R., Ardau, C., 2012. Short-term changes in water chemistry in the Baccu Locci stream (Sardinia, Italy) affected by past mining, Appl. Geochem. doi: 10.1016/j.apgeochem.2012.02.019.

Fuller, C.C., Harvey, J.W., 2000. Reactive uptake of trace metals in the hyporheic zone of a mining-contaminated stream, Pinal Creek, Arizona. Environ. Sci. Technol. 34, 1150-1155.

Gandy, C.J., Smith, J.W.N., Jarvis, A.P., 2007. Attenuation of mining-derived pollutants in the hyporheic zone: A review. Sci. Total Environ. 373, 435-446.

Gozzard E., Mayes W.M, Potter H.A, Jarvis A.P., 2011. Seasonal and spatial variation of diffuse (non-point) source zinc pollution in a historically metal mined river catchment, UK. Environ. Pollut. 159, 3113-3122.

Harper, M.P., Davison, W., Zhang, H., Tych, W. 1998. Kinetics of metal exchange between solids and solutions in sediments and soils interpreted from DGT measured fluxes.

Geochem. Cosmochim. Acta 62, 2757-2770.

Harvey, J.W., Fuller, C.F., 1998. Effect of enhanced manganese oxidation in hyporheic zone on basin-scale geochemical mass balance. Water Resour. Res. 34, 623-636. 
Kimball, B.A., Broshears, R.E., Bencala, K.E., McKnight, D.M., 1994. Coupling of Hydrologic Transport and Chemical Reactions in a Stream Affected by Acid Mine Drainage. Environ. Sci. Technol. 28, 2065-2073.

Kimball, B.A., Runkel, R.L., Walton-Day, K., Bencala, K.E., 2002. Assessment of metal loads in watersheds affected by acid mine drainage by using tracer injection and synoptic sampling: Cement Creek, Colorado, USA. Appl. Geochem. 17, 1183-1207.

Malcolm, I., Soulsby, C., Youngson, A., Tetzlaff, D., 2009. Fine scale variability of hyporheic hydrochemistry in salmon spawning gravels with contrasting groundwatersurface water interactions. Hydrogeol. J. 17, 161-174.

Mayes, W.M., Potter, H.A.B., Jarvis, A.P., 2010. Inventory of aquatic contaminant flux arising from historical metal mining in England and Wales. Sci. Total Environ. 408, 17, 3576-3583.

Nagorski, S.A., Moore, J.N., 1999. Arsenic mobilization in the hyporheic zone of a contaminated stream. Water Resour. Res. 35, 3441-3450.

Nimick, D.A., Gammons, C.H., Parker, S. R., 2011. Diel biogeochemical processes and their effect on the aqueous chemistry of streams: A review, Chem. Geol. 283, 1-2, 3-17.

Nordstrom, D.K., Jenne, E.A., Ball, J.W., 1979. Redox equilibria of iron in acid mine waters. In: Jenne, E. A. (Ed.), Chemical Modelling in Aqueous Systems. Am. Chem. Soc. Symp. Series 93, 51-80.

Novak J.M., Stone K.C., Szogi A.A., Watts D.W., Johnson M.H., 2004. Dissolved phosphorus retention and release from a coastal plain in-stream wetland. J Environ. Qual. 33, 394-401.

Palumbo-Roe, B., Wragg, J., Banks, V.J., 2012. Lead mobilisation in the hyporheic zone and river bank sediments of a contaminated stream: contribution to diffuse pollution. J Soil Sed. 12, 1633-1640.

Parkhurst, D.L., Appelo, C.A.J., 1999, User's guide to PHREEQC (version 2)--A computer program for speciation, batch-reaction, one-dimensional transport, and inverse geochemical calculations: U.S. Geol. Surv. Water-Resour. Invest. Rep. 99-4259.

Rivett, M.O., Ellis, P.A., Greswell, R.B., Ward, R.S., Roche, R.S., Cleverly, M.G., Walker, C., Conran, D., Fitzgerald, P.J., Willcox, T., Dowle, J., 2008. Cost-effective mini drivepoint piezometers and multilevel samplers for monitoring the hyporheic zone. Q. J. Engin. Geol. Hydrogeol. 41, 49-60.

Sandén, P., Karlsson, S., Düker, A., Ledin, A., Lundman, L., 1997. Variations in hydrochemistry, trace metal concentration and transport during a rain storm event in a small catchment, J. Geochem. Explor. 58, 2-3, 145-155.

Shope, C.L., Xie, Y., Gammons, C.H., 2006. The influence of hydrous Mn-Zn oxides on diel cycling of $\mathrm{Zn}$ in an alkaline stream draining abandoned mine lands. Appl. Geochem. 21, 476-491.

Smith, S.L., Jaffé, P.R., 1998. Modeling the transport and reaction of trace metals in watersaturated soils and sediments. Water Resour. Res. 34, 3135-3147.

Søndergaard, J., Elberling, B., Asmund, G. 2008. Metal speciation and bioavailability in acid mine drainage from a high Arctic coal mine waste rock pile: temporal variations assessed through high-resolution water sampling, geochemical modelling and DGT. Cold Regions Sci. Technol. 54, 89-96.

Strömberg, B., Banwart, S., 1999. Weathering kinetics of waste rock from the Aitik copper mine, Sweden: scale dependent rate factors and $\mathrm{pH}$ controls in large column experiments, J. Contam. Hydrol. 39, 59-89.

Sullivan, A.B., Drever, J.I., 2001. Spatiotemporal variability in stream chemistry in a highelevation catchment affected by mine drainage. J. Hydrol. 252, 237-250. 
Tebo, B.M., Johnson, H.A., McCarthy, J.K., Templeton, A.S., 2005. Geomicrobiology of manganese(II) oxidation. Trends Microbiol. 13, 421-428.

Van Damme, A., Degryse, F., Smolders, E., Sarret, G., Dewit, J., Swennen, R., Manceau, A., 2010. Zinc speciation in mining and smelter contaminated overbank sediments by EXAFS spectroscopy. Geochim Cosmochim Acta, 74, 13, 3707-3720.

Von Gunten, H.R., Karametaxas, G., Krähenbühl, U., Kuslys, M., Giovanoli, R., Hoehn, E., Keil, R., 1991. Seasonal biogeochemical cycles in riverborne groundwater. Geochim Cosmoch Acta 55, 3597-3609.

Wondzell, S.M., 2011. The role of the hyporheic zone across stream networks. Hydrol. Process.Wiley Online Library DOI: 10.1002/hyp.8119.

Zhang, H., Davison, W., 1995. Performance Characteristics of Diffusion Gradients in Thin Films for the in Situ Measurement of Trace Metals in Aqueous Solution. Anal. Chem. 67, 3391-3400.

Zhang, H., Davison, W., Knight, B., McGrath, S., 1998. In situ measurement of solution concentrations and fluxes of trace metals in soils using DGT. Environ. Sci. Technol. 32, 704-710.

Zhang, H., Davison, W., Miller, S., Tych, W., 1995. In situ high resolution measurements of fluxes of $\mathrm{Ni}, \mathrm{Cu}, \mathrm{Fe}$, and $\mathrm{Mn}$ and concentrations of $\mathrm{Zn}$ and $\mathrm{Cd}$ in porewaters by DGT. Geochim. Cosmochim. Acta 59, 4181-4192. 
Table 1 - Averages and range of physico-chemical parameters and elemental concentrations of surface water samples collected in the hyporheic zone in July 2010 and October 2010.

\begin{tabular}{|c|c|c|c|c|c|c|c|c|c|c|c|c|c|c|}
\hline & & Temp & Eh & $\mathrm{pH}$ & $\mathrm{HCO}_{3}^{-}$ & Cond & $\mathrm{Ca}$ & $\mathrm{Mg}$ & $\mathrm{Na}$ & K & $\mathrm{Cl}^{-}$ & $\mathrm{SO}_{4}^{2-}$ & $\mathrm{NO}_{3}^{-}$ & $\mathrm{F}^{-}$ \\
\hline & & ${ }^{\circ} \mathrm{C}$ & $\mathrm{mV}$ & & $\mathrm{mgl}^{-1}$ & $\mu \mathrm{Scm}^{-1}$ & $\mathrm{mgl}^{-1}$ & $\mathrm{mgl}^{-1}$ & $\mathrm{mgl}^{-1}$ & $\mathrm{mgl}^{-1}$ & $\mathrm{mgl}^{-1}$ & $\mathrm{mgl}^{-1}$ & $\mathrm{mgl}^{-1}$ & $\mathrm{mgl}^{-1}$ \\
\hline \multicolumn{15}{|c|}{ Surface water } \\
\hline Jul-10 & average & 15.8 & 455 & - & 98.7 & 473 & 64.2 & 12.0 & 11.3 & 4.72 & 11.1 & 89.4 & 0.24 & 1.70 \\
\hline \multicolumn{15}{|c|}{ Surface water } \\
\hline \multirow[t]{2}{*}{ Oct-10 } & average & 4.8 & 386 & - & 69.0 & 312 & 38.1 & 6.76 & 6.98 & 2.73 & 8.91 & 50.7 & 0.26 & 1.15 \\
\hline & range & (3.5-5.7) & (359-411) & $(7.48-8.04)$ & $(46-93)$ & (306-321) & (37.8-38.4) & $(6.69-6.87)$ & (6.9-7.1) & $(2.71-2.76)$ & $(8.79-9.00)$ & $(49.90-51.48)$ & $(0.18-0.35)$ & $(1.15-1.17)$ \\
\hline \multicolumn{15}{|c|}{ Borehole } \\
\hline \multirow[t]{3}{*}{ Oct-10 } & & nd & nd & nd & nd & nd & 60.60 & 11.15 & 10.00 & 11.17 & 6.89 & 9.85 & 0.57 & 0.71 \\
\hline & & NPOC & Total S & $\mathrm{Si}$ & $\mathrm{SiO}_{2}$ & $\mathrm{Ba}$ & $\mathrm{Sr}$ & Mn & Total Fe & Fe (II) & $\mathrm{Li}$ & $\mathrm{Be}$ & B & $\mathrm{Al}$ \\
\hline & & $\mathrm{mgl}^{-1}$ & $\mathrm{mgl}^{-1}$ & $\mathrm{mgl}^{-1}$ & $\mathrm{mgl}^{-1}$ & $\mu \mathrm{gl}^{-1}$ & $\mu \mathrm{gl}^{-1}$ & $\mu \mathrm{gl}^{-1}$ & $\left.\mu g\right|^{-1}$ & $\left.\mu g\right|^{-1}$ & $\mu \mathrm{gl}^{-1}$ & $\mu \mathrm{gl}^{-1}$ & $\left.\mu g\right|^{-1}$ & $\mu \mathrm{gl}^{-1}$ \\
\hline \multicolumn{15}{|c|}{ Surface water } \\
\hline \multirow[t]{2}{*}{ Jul-10 } & average & 1.50 & 30.3 & 2.79 & 5.96 & 16.2 & 301 & 160 & 33.60 & $<0.50$ & 17.03 & 0.12 & 24.5 & 10.7 \\
\hline & range & $(1.44-1.60)$ & (29.3-31.4) & $(2.7-2.84)$ & (5.78-6.08) & (15.62-17.49) & $(298-304)$ & (138-179) & $(15.1-60.6)$ & - & $(16.8-17.3)$ & $(0.11-0.14)$ & $(24-25)$ & $(9.8-12.4)$ \\
\hline \multicolumn{15}{|c|}{ Surface water } \\
\hline \multirow[t]{2}{*}{ Oct-10 } & average & 4.05 & 19.8 & 2.325 & 4.97 & 11.5 & 168 & 496 & 461 & 402 & 10.5 & 0.42 & 14.8 & 55.0 \\
\hline & range & $(3.92-4.19)$ & $(19-20)$ & $(2.31-2.35)$ & $(4.94-5.03)$ & $(11.3-11.7)$ & $(165-171)$ & $(472-516)$ & (443-481) & (392-407) & $(10-11)$ & $(0.41-0.43)$ & $(12-20)$ & (52-57) \\
\hline \multicolumn{15}{|c|}{ Borehole } \\
\hline \multirow{2}{*}{ Oct-10 } & & $\mathrm{Cr}$ & Co & $\mathrm{Ni}$ & $\mathrm{Cu}$ & $\mathrm{Zn}$ & As & Se & $\mathrm{Rb}$ & $\mathrm{Cd}$ & $\mathrm{Sb}$ & Cs & $\mathrm{Pb}$ & $\mathrm{U}$ \\
\hline & & $\mu \mathrm{gl}^{-1}$ & $\mu \mathrm{gl}^{-1}$ & $\left.\mu g\right|^{-1}$ & $\mu \mathrm{gl}^{-1}$ & $\mu \mathrm{gl}^{-1}$ & $\mu \mathrm{gl}^{-1}$ & $\mu \mathrm{gl}^{-1}$ & $\mu \mathrm{gl}^{-1}$ & $\mu \mathrm{gl}^{-1}$ & $\mu \mathrm{gl}^{-1}$ & $\mu \mathrm{gl}^{-1}$ & $\mu \mathrm{gl}^{-1}$ & $\mu \mathrm{gl}^{-1}$ \\
\hline \multicolumn{15}{|c|}{ Surface water } \\
\hline \multirow[t]{2}{*}{ Jul-10 } & average & 0.021 & 0.44 & 3.69 & 2.50 & 69.0 & 0.243 & 0.095 & 18.0 & 0.113 & 0.943 & 0.368 & 2.87 & 0.473 \\
\hline & range & $(0.01-0.04)$ & $(0.35-0.52)$ & $(3.43-4.01)$ & $(1-7)$ & $(60-82)$ & $(0.2-0.27)$ & $(0.08-0.11)$ & (17.4-18.5) & $(0.1-0.12)$ & $(0.92-0.97)$ & $(0.35-0.38)$ & (1.6-4.17) & $(0.466-0.478)$ \\
\hline \multicolumn{15}{|c|}{ Surface water } \\
\hline \multirow[t]{2}{*}{ Oct-10 } & average & 0.190 & 2.06 & 6.78 & 0.85 & 166 & 0.423 & $<0.1$ & 10.5 & 0.188 & 0.383 & 0.211 & 5.42 & 0.211 \\
\hline & range & $(0.1-0.45)$ & $(1.96-2.2)$ & $(6.5-7.2)$ & $(0.8-1)$ & $(150-184)$ & $(0.32-0.68)$ & - & $(10.4-10.6)$ & $(0.18-0.2)$ & (0.379-0.388) & $(0.2-0.217)$ & $(5.1-5.61)$ & $(0.206-0.216)$ \\
\hline \multicolumn{2}{|c|}{ Borehole } & & & & & & & & & & & & & \\
\hline Oct-10 & & 0.06 & $<0.01$ & 0.10 & 0.90 & 4.90 & 0.04 & $<0.1$ & 50.5 & $<0.01$ & 0.055 & 0.917 & 0.060 & 0.011 \\
\hline
\end{tabular}


Table 2 - Averages and range of physico-chemical parameters and elemental concentrations of pore water samples collected in the hyporheic zone in July 2010 and October 2010.

\begin{tabular}{|c|c|c|c|c|c|c|c|c|c|c|c|c|c|c|c|c|c|}
\hline & & \multicolumn{4}{|c|}{ Point 1} & \multicolumn{4}{|c|}{ Point 2} & \multicolumn{4}{|c|}{ Point 3} & \multicolumn{4}{|c|}{ Point 4} \\
\hline & & \multicolumn{2}{|r|}{ Jul-10 } & \multicolumn{2}{|c|}{ Oct-10 } & \multicolumn{2}{|r|}{ Jul-10 } & \multicolumn{2}{|c|}{ Oct-10 } & \multicolumn{2}{|r|}{ Jul-10 } & \multicolumn{2}{|c|}{ Oct-10 } & \multicolumn{2}{|c|}{ Jul-10 } & \multicolumn{2}{|c|}{ Oct-10 } \\
\hline & & average & range & average & range & average & range & average & range & average & range & average & range & average & range & average & range \\
\hline Temp & ${ }^{\circ} \mathrm{C}$ & nd & nd & 4.9 & $(4.9-4.9)$ & nd & (nd) & nd & (nd) & nd & (nd) & nd & (nd) & nd & (nd) & nd & (nd) \\
\hline Eh & mVolt & 448 & $(441-454)$ & 335 & $(321-340)$ & 463 & $(448-474)$ & 396 & $(389-404)$ & 378 & $(239-438)$ & 363 & $(356-369)$ & 413 & $(291-463)$ & 347 & (338-355) \\
\hline $\mathrm{pH}$ & & - & $(7.86-8.36)$ & - & $(7.8-8.03)$ & 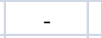 & $(7.72-8.3)$ & - & $(7.87-8.12)$ & - & $(7.35-8.34)$ & - & $(7.49-7.9)$ & - & $(7.48-7.69)$ & & $(7.32-7.57)$ \\
\hline $\mathrm{HCO}_{3}^{-}$ & $\mathrm{mg} \mathrm{L}^{-1}$ & 98 & $(89-105)$ & 52 & $(49-60)$ & 106 & $(100-114)$ & nd & (nd) & 123 & $(107-137)$ & 104 & $(93-122)$ & 91 & $(77-109)$ & 76 & $(41-151)$ \\
\hline $\mathrm{Ca}$ & $\mathrm{mg} \mathrm{L}^{-1}$ & 62.2 & (60.9-63.6) & 37.4 & $(36.6-37.8)$ & 62.3 & (61.5-63.1) & 37.7 & $(36.7-38.4)$ & 71.4 & $(62.4-84.8)$ & 41.0 & $(37.7-49.2)$ & 62.8 & (60.9-65.7) & 44.6 & $(41.7-54)$ \\
\hline $\mathrm{Mg}$ & $\mathrm{mg} \mathrm{L}^{-1}$ & 11.8 & $(11.7-11.9)$ & 6.68 & (6.58-6.84) & 11.7 & (11.5-11.9) & 6.70 & $(6.64-6.81)$ & 12.2 & $(11.7-13.6)$ & 6.76 & $(6.35-7.12)$ & 11.6 & (11.4-11.8) & 7.03 & $(6.65-8.44)$ \\
\hline $\mathrm{Na}$ & $\mathrm{mg} \mathrm{L}^{-1}$ & 11.0 & (10.8-11.3) & 6.95 & (6.8-7.1) & 11.0 & (10.9-11.1) & 7.10 & $(7-7.2)$ & 22.1 & $(11.2-42.36)$ & 8.05 & $(7-10.8)$ & 11.1 & (10.9-11.3) & 8.76 & $(7.4-13.3)$ \\
\hline $\mathrm{K}$ & $\mathrm{mg} \mathrm{L}^{-1}$ & 4.62 & $(4.56-4.75)$ & 2.95 & $(2.79-3.19)$ & 4.70 & $(4.66-4.73)$ & 6.57 & $(2.86-10.9)$ & 4.87 & $(4.55-5.48)$ & 9.57 & (3.07-19.5) & 4.40 & $(4.26-4.59)$ & 5.49 & $(4.07-7.43)$ \\
\hline $\mathrm{Cl}^{-}$ & $\mathrm{mg} \mathrm{L}^{-1}$ & 12.34 & (11.2-13.8) & 9.13 & (8.88-9.57) & 11.1 & (11.0-11.2) & 11.8 & (8.98-17.2) & 43.2 & (11.5-100) & 17.0 & $(9.64-30.47)$ & 10.9 & $(9.91-11.23)$ & 16.8 & $(13.7-30.1)$ \\
\hline $\mathrm{SO}_{4}^{2-}$ & $\mathrm{mg} \mathrm{L}^{-1}$ & 90.5 & (90.2-91.3) & 50.1 & (49.9-50.3) & 91.1 & (90.9-91.4) & 51.1 & (50.8-51.5) & 79.8 & (59.4-90.1) & 51.6 & $(50.4-54.3)$ & 89.3 & (82.6-91.8) & 51.4 & $(48.1-52.2)$ \\
\hline $\mathrm{NO}_{3}^{-}$ & $\mathrm{mg} \mathrm{L}^{-1}$ & 0.33 & $(0.30-0.42)$ & 0.36 & $(0.29-0.53)$ & 0.51 & $(0.23-0.73)$ & 0.24 & $(<0.02-0.51)$ & 0.12 & $(<0.03-0.25)$ & 0.27 & $(<0.02-0.90)$ & 0.44 & $(0.25-0.51)$ & 0.18 & $(<0.02-0.33)$ \\
\hline $\mathrm{F}^{-}$ & $\mathrm{mg} \mathrm{L}^{-1}$ & 1.80 & $(1.74-1.95)$ & 1.15 & (1.14-1.17) & 1.79 & $(1.76-1.85)$ & 1.20 & $(1.16-1.24)$ & 1.85 & $(1.74-1.96)$ & 1.33 & $(1.16-1.70)$ & 1.72 & $(1.67-1.74)$ & 1.32 & $(1.21-1.73)$ \\
\hline NPOC & $\mathrm{mg} \mathrm{L}^{-1}$ & 2.19 & $(<3-4.57)$ & 4.15 & $(2.19-4.71)$ & 1.62 & $(1.57-1.66)$ & 5.90 & $(4.08-11.0)$ & 2.32 & $(1.71-3.01)$ & 9.41 & (4.42-18.8) & $<3$ & - & 4.49 & (3.03-6.01) \\
\hline Tot S & $\mathrm{mg} \mathrm{L}^{-1}$ & 29.4 & (28.9-29.8) & 20 & $(20-20)$ & 30.33 & $(29.7-31)$ & 20.0 & $(20-20)$ & 26.6 & $(19.8-30.5)$ & 20.4 & $(19-22)$ & 30.4 & $(29.8-31)$ & 20.1 & $(19-21)$ \\
\hline $\mathrm{Si}$ & $\mathrm{mg} \mathrm{L}^{-1}$ & 2.83 & $(2.78-2.87)$ & 2.32 & $(2.27-2.37)$ & 2.78 & $(2.66-2.86)$ & 2.28 & $(2.23-2.33)$ & 2.88 & $(2.51-3.34)$ & 2.27 & $(2.19-2.32)$ & 2.62 & $(2.54-2.76)$ & 2.09 & $(2-2.44)$ \\
\hline $\mathrm{SiO}_{2}$ & $\mathrm{mg} \mathrm{L}^{-1}$ & 6.05 & (5.95-6.14) & 4.96 & $(4.86-5.07)$ & 5.95 & (5.69-6.12) & 4.88 & $(4.77-4.98)$ & 6.17 & $(5.37-7.15)$ & 4.85 & $(4.69-4.96)$ & 5.60 & (5.43-5.90) & 4.47 & $(4.28-5.22)$ \\
\hline $\mathrm{Ba}$ & $\mu \mathrm{g} \mathrm{L}^{-1}$ & 18.2 & $(16.4-22.7)$ & 11.4 & (11.2-11.6) & 19.6 & $(15.9-24.5)$ & 13.7 & (11.7-15.3) & 32.0 & (15.6-51.5) & 15.9 & $(12.1-24.6)$ & 31.8 & (29.4-33.9) & 16.8 & $(15-23)$ \\
\hline $\mathrm{Sr}$ & $\mu \mathrm{g} \mathrm{L}^{-1}$ & 296 & $(293-298)$ & 163 & $(161-166)$ & 297 & $(291-303)$ & 165 & $(165-166)$ & 349 & (296.4-432.15) & 178 & $(167-206)$ & 298 & $(285-324)$ & 193 & $(181-234)$ \\
\hline $\mathrm{Mn}$ & $\mu \mathrm{g} \mathrm{L}^{-1}$ & 138 & (91.2-175) & 284 & (25.5-507) & 56 & $(9.67-127)$ & 255 & (30.6-433) & 1781 & $(146-3487)$ & 207 & $(30-468)$ & 57.8 & (23.6-118) & 23.4 & $(9-54.2)$ \\
\hline Tot Fe & $\mu \mathrm{g} \mathrm{L}^{-1}$ & 22.7 & $(12.1-37)$ & 395 & (315-454) & 11 & (7.7-15.9) & 381 & (232-472) & 10.1 & $(4.3-14.6)$ & 252 & $(50-452)$ & 10.5 & $(8.4-11.8)$ & 72.0 & (22-125) \\
\hline $\mathrm{Fe}$ (II) & $\mu \mathrm{g} \mathrm{L}^{-1}$ & $<0.5$ & - & 378 & (312-422) & $<0.5$ & $(<0.5-0.76)$ & nd & nd & $<0.5$ & - & nd & nd & $<0.5$ & - & nd & nd \\
\hline $\mathrm{Li}$ & $\mu \mathrm{g} \mathrm{L}^{-1}$ & 18.2 & $(18-18.4)$ & 10.8 & $(10-11)$ & 17.8 & $(17.5-18)$ & 10.6 & $(10-11)$ & 15.6 & (10.6-17.7) & 10.1 & $(8-13)$ & 15.4 & (15-15.6) & 9.00 & $(8-10)$ \\
\hline $\mathrm{Be}$ & $\mu \mathrm{g} \mathrm{L}^{-1}$ & 0.065 & $(0.028-0.097)$ & 0.31 & $(0.17-0.42)$ & 0.067 & $(0.044-0.106)$ & 0.278 & $(0.14-0.37)$ & 0.085 & (0.046-0.119) & 0.19 & $(0.03-0.36)$ & 0.04 & $(0.02-0.04)$ & 0.06 & $(0.03-0.08)$ \\
\hline B & $\mu \mathrm{g} \mathrm{L}^{-1}$ & 34.8 & (33-37) & 16.6 & (15-19) & 30.8 & $(30-31)$ & 14.4 & (13-16) & 26.3 & (24-29) & 12.8 & (11-14) & 23.0 & (22-24) & - & $(<10-13)$ \\
\hline $\mathrm{Al}$ & $\mu \mathrm{g} \mathrm{L}^{-1}$ & 8.8 & $(5.4-10.3)$ & 39.8 & (27-51) & 8.4 & $(5.2-14.6)$ & 42.4 & $(21-55)$ & 8.43 & $(4.7-12.2)$ & 30.6 & $(9-57)$ & 4.48 & $(3.7-5.4)$ & 10.1 & (5-15) \\
\hline $\mathrm{Cr}$ & $\mu \mathrm{g} \mathrm{L}^{-1}$ & 0.068 & $(0.035-0.14)$ & 0.128 & $(0.11-0.15)$ & 0.034 & $(0.029-0.041)$ & 0.156 & $(0.12-0.2)$ & 0.030 & $(0.017-0.043)$ & 0.126 & $(0.06-0.25)$ & 0.037 & $(0.03-0.04)$ & 0.060 & $(<0.05-0.09)$ \\
\hline Сo & $\mu \mathrm{g} \mathrm{L}^{-1}$ & 0.423 & $(0.341-0.534)$ & 1.19 & $(0.18-2.11)$ & 0.208 & $(0.086-0.341)$ & 1.08 & $(0.21-1.77)$ & 1.55 & $(0.375-2.96)$ & 0.81 & $(0.16-1.88)$ & 0.208 & $(0.14-0.34)$ & 0.149 & $(0.08-0.26)$ \\
\hline $\mathrm{Ni}$ & $\mu \mathrm{g} \mathrm{L}^{-1}$ & 3.81 & (3.46-4.13) & 5.63 & $(3.6-7.1)$ & 2.50 & $(1.87-3.18)$ & 5.20 & $(3.2-6.7)$ & 4.81 & $(3.22-6.68)$ & 4.53 & $(2.9-6.8)$ & 2.86 & $(2.21-3.33)$ & 1.97 & $(1.7-2.4)$ \\
\hline $\mathrm{Cu}$ & $\mu \mathrm{g} \mathrm{L}^{-1}$ & 1.25 & $(1-2)$ & 1.66 & $(1-2.9)$ & - & $(<1-2)$ & 5.42 & $(2.2-14.8)$ & - & $(<1-1)$ & 2.45 & $(1.1-4.3)$ & 1.25 & $(1-2)$ & 3.57 & (2.4-8.3) \\
\hline $\mathrm{Zn}$ & $\mu \mathrm{g} \mathrm{L}^{-1}$ & 103.3 & (74-163) & 121 & (57-174) & 78 & $(41-136)$ & 108 & (63.3-141) & 119 & (56-219) & 80.8 & (38.7-141.8) & 314 & (230-392) & 70.8 & (58.3-86) \\
\hline As & $\mu \mathrm{g} \mathrm{L}^{-1}$ & 0.24 & $(0.2-0.27)$ & 0.309 & $(0.28-0.35)$ & 0.18 & $(0.11-0.24)$ & 0.314 & $(0.26-0.35)$ & 0.360 & $(0.21-0.59)$ & 0.283 & $(0.24-0.34)$ & 0.190 & $(0.16-0.23)$ & 0.221 & $(0.2-0.24)$ \\
\hline Se & $\mu \mathrm{g} \mathrm{L}^{-1}$ & 0.108 & $(0.09-0.12)$ & $<0.1$ & - & 0.083 & $(0.06-0.1)$ & $<0.1$ & - & 0.078 & $(0.05-0.1)$ & $<0.1$ & 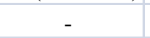 & 0.055 & $(0.04-0.07)$ & - & $(<0.10 .1)$ \\
\hline $\mathrm{Rb}$ & $\mu \mathrm{g} \mathrm{L}^{-1}$ & 17.1 & $(16.1-17.8)$ & 9.86 & (9.12-10.5) & 17.9 & $(16.6-18.6)$ & 9.92 & $(8.61-10.8)$ & 20.4 & $(15.6-29.7)$ & 9.55 & (7.41-11.08) & 14.3 & $(14.0-14.5)$ & 8.52 & $(7.8-11.03)$ \\
\hline $\mathrm{Cd}$ & $\mu \mathrm{g} \mathrm{L}^{-1}$ & 0.21 & $(0.13-0.35)$ & 0.184 & $(0.15-0.23)$ & 0.128 & $(0.07-0.26)$ & 0.220 & $(0.17-0.3)$ & 0.508 & $(0.09-1.37)$ & 0.203 & $(0.12-0.29)$ & 0.523 & $(0.34-0.81)$ & 0.187 & $(0.12-0.33)$ \\
\hline Sb & $\mu \mathrm{g} \mathrm{L}^{-1}$ & 1.36 & $(0.929-2.52)$ & 0.472 & $(0.395-0.639)$ & 1.68 & $(0.986-2.62)$ & 0.664 & $(0.44-1.02)$ & 2.06 & $(0.941-5.19)$ & 1.28 & $(0.48-2.97)$ & 3.48 & $(3.12-3.83)$ & 2.38 & $(2.24-2.46)$ \\
\hline Cs & $\mu \mathrm{g} \mathrm{L}^{-1}$ & 0.291 & $(0.244-0.348)$ & 0.177 & $(0.109-0.223)$ & 0.308 & $(0.244-0.413)$ & 0.255 & $(0.122-0.404)$ & 0.416 & $(0.34-0.589)$ & 0.269 & $(0.16-0.53)$ & 0.254 & $(0.24-0.28)$ & 0.179 & $(0.15-0.23)$ \\
\hline $\mathrm{Pb}$ & $\mu \mathrm{g} \mathrm{L}^{-1}$ & 17.6 & (5.51-24.7) & 24.4 & (6.97-56.7) & 8.43 & $(3.86-12.8)$ & 31.1 & $(20.3-48.2)$ & 13.4 & (1.99-37.43) & 26.3 & (12.5-43.5) & 9.47 & (8.67-10.8) & 20.2 & $(10.8-31.7)$ \\
\hline $\mathrm{U}$ & $\mu \mathrm{g} \mathrm{L}^{-1}$ & 0.497 & $(0.469-0.564)$ & 0.219 & $(0.208-0.238)$ & 0.517 & $(0.487-0.568)$ & 0.226 & $(0.219-0.234)$ & 0.577 & $(0.481-0.735)$ & 0.282 & $(0.213-0.408)$ & 0.554 & $(0.544-0.558)$ & 0.239 & $(0.193-0.439)$ \\
\hline
\end{tabular}


Table 3- DGT-measured fluxes of $\mathrm{Zn}, \mathrm{Pb}, \mathrm{Mn}$ and Fe of the sediment pore water at a sediment depth sampling resolution of $150 \mathrm{~mm}$.

\begin{tabular}{|l|c|c|c|c|}
\hline & Flux Fe & Flux Mn & Flux Pb & Flux Zn \\
\hline & $10^{-3} \mathrm{mg} \mathrm{cm}^{-2} \mathrm{~s}^{-1}$ & $10^{-3} \mathrm{mg} \mathrm{cm}^{-2} \mathrm{~s}^{-1}$ & $10^{-3} \mathrm{mg} \mathrm{cm}^{-2} \mathrm{~s}^{-1}$ & $10^{-3} \mathrm{mg} \mathrm{cm}^{-2} \mathrm{~s}^{-1}$ \\
\hline Sediment probe DGT Sampler & & & & \\
\hline $\begin{array}{c}\text { depth interval below } \\
\text { surface (cm) }\end{array}$ & & & & \\
\hline $0-1.5$ & & & & \\
\hline $1.5-3.0$ & 0.00026 & 0.00420 & 0.00068 & 0.0039 \\
\hline $3.0-4.5$ & 0.00010 & 0.00025 & 0.00085 & 0.0028 \\
\hline $4.5-6.0$ & 0.00023 & 0.00026 & 0.00087 & 0.0026 \\
\hline $6.0-7.5$ & 0.00011 & 0.00061 & 0.00138 & 0.0030 \\
\hline $7.5-9.0$ & 0.00027 & 0.00057 & 0.00201 & 0.0046 \\
\hline $9.0-10.5$ & 0.00012 & 0.00057 & 0.00225 & 0.0050 \\
\hline $10.5-12.0$ & 0.00015 & 0.00063 & 0.00250 & 0.0043 \\
\hline $12.0-13.5$ & 0.00017 & 0.00094 & 0.00315 & 0.0056 \\
\hline & 0.00012 & 0.00099 & 0.00270 & 0.0056 \\
\hline
\end{tabular}

Table 4 - Net changes in loads of Mn, Zn and Pb for a $700 \mathrm{~m}$ stream stretch including the study site in the Rookhope Burn.

\begin{tabular}{|c|c|c|}
\hline \multicolumn{3}{|c|}{ Surface water at the piezometer point } \\
\hline & $\mathrm{Zn}$ & $\mathrm{Pb}$ \\
\hline DGT conc $\left(\mu g \mathrm{~L}^{-1}\right)$ & 77 & 2.40 \\
\hline Total conc $\left(\mu g \mathrm{~L}^{-1}\right)$ & 58 & 2.71 \\
\hline reap \% & 28 & 12 \\
\hline \multicolumn{3}{|c|}{ Pore water at the piezometer point } \\
\hline & $\mathrm{Zn}$ & $\mathrm{Pb}$ \\
\hline DGT conc $\left(\mu g \mathrm{~L}^{-1}\right)$ & 140 & 29 \\
\hline Total conc $\left(\mu \mathrm{g} \mathrm{L} \mathrm{L}^{-1}\right)$ & 158 & 35 \\
\hline reap \% & 12 & 19 \\
\hline
\end{tabular}




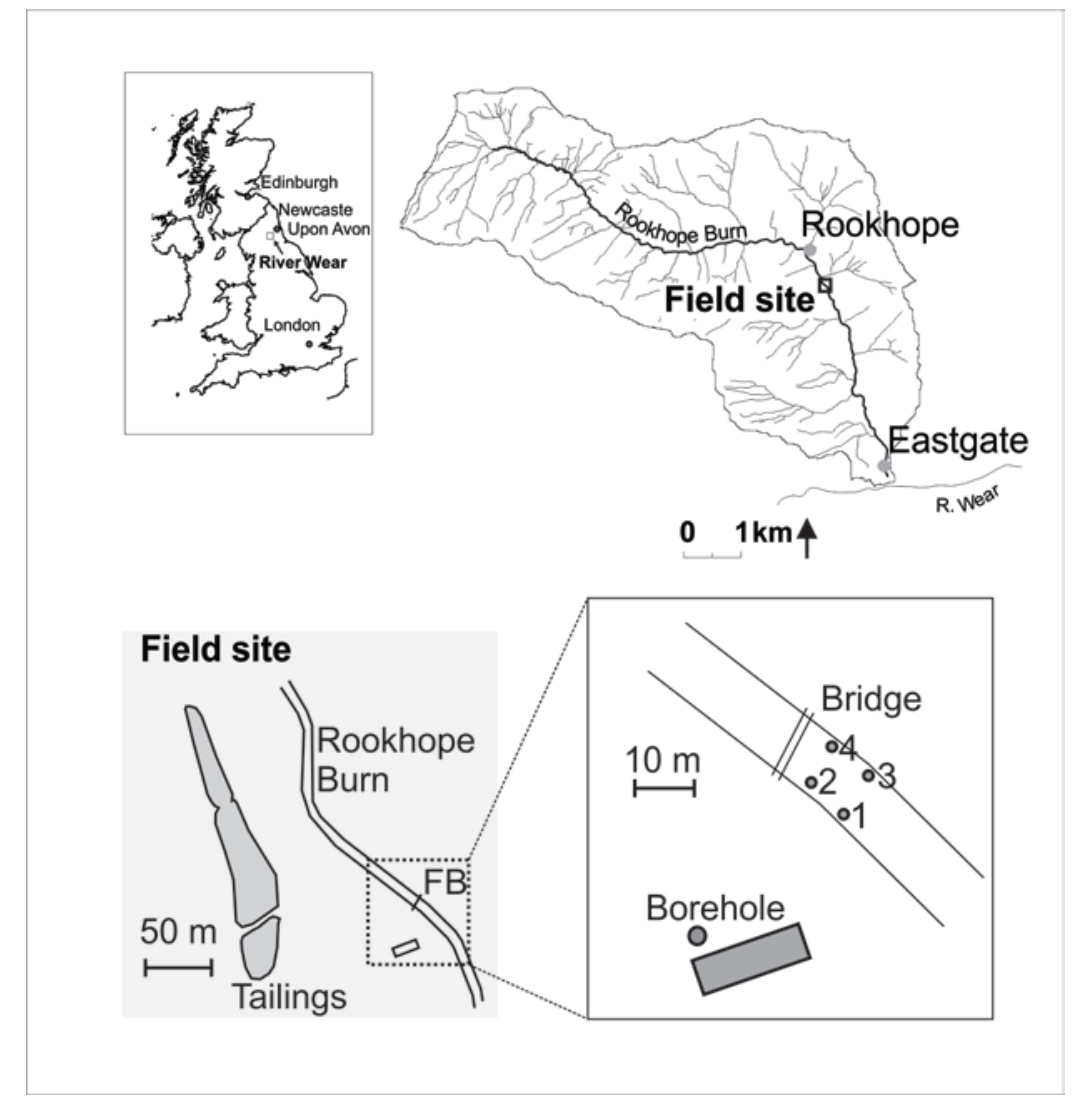

Figure 1 - Map of the Rookhope Burn catchment detailing the study site location and sampling points. 


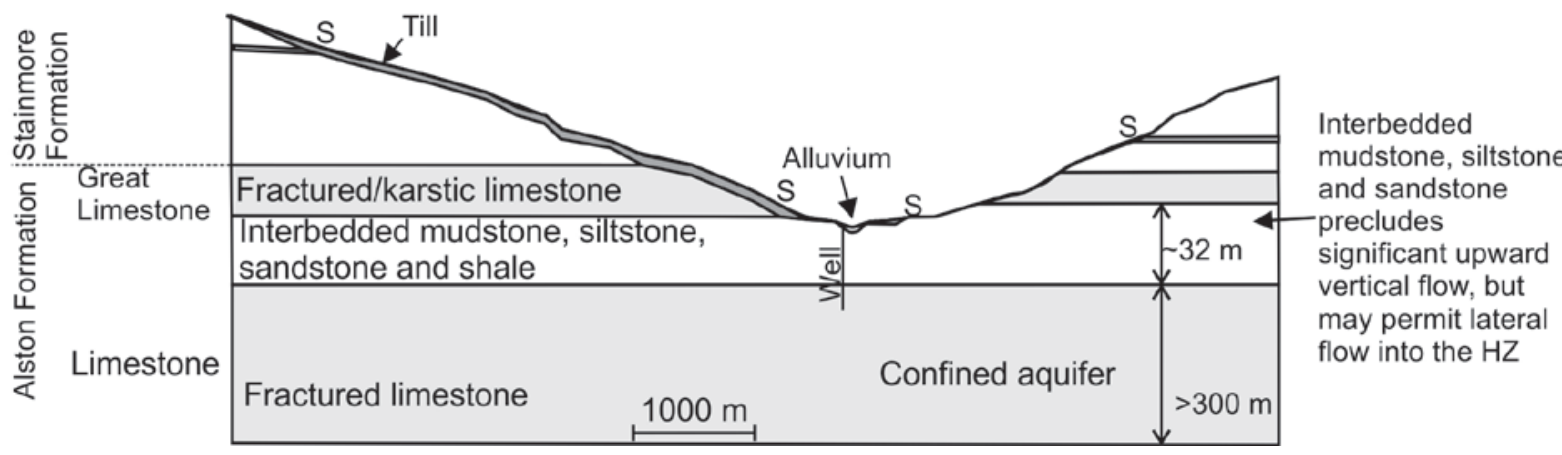

Figure 2 - Schematic representation of the geology and hydrogeology along a SW-NE orientated transect across the Rookhope Valley. 


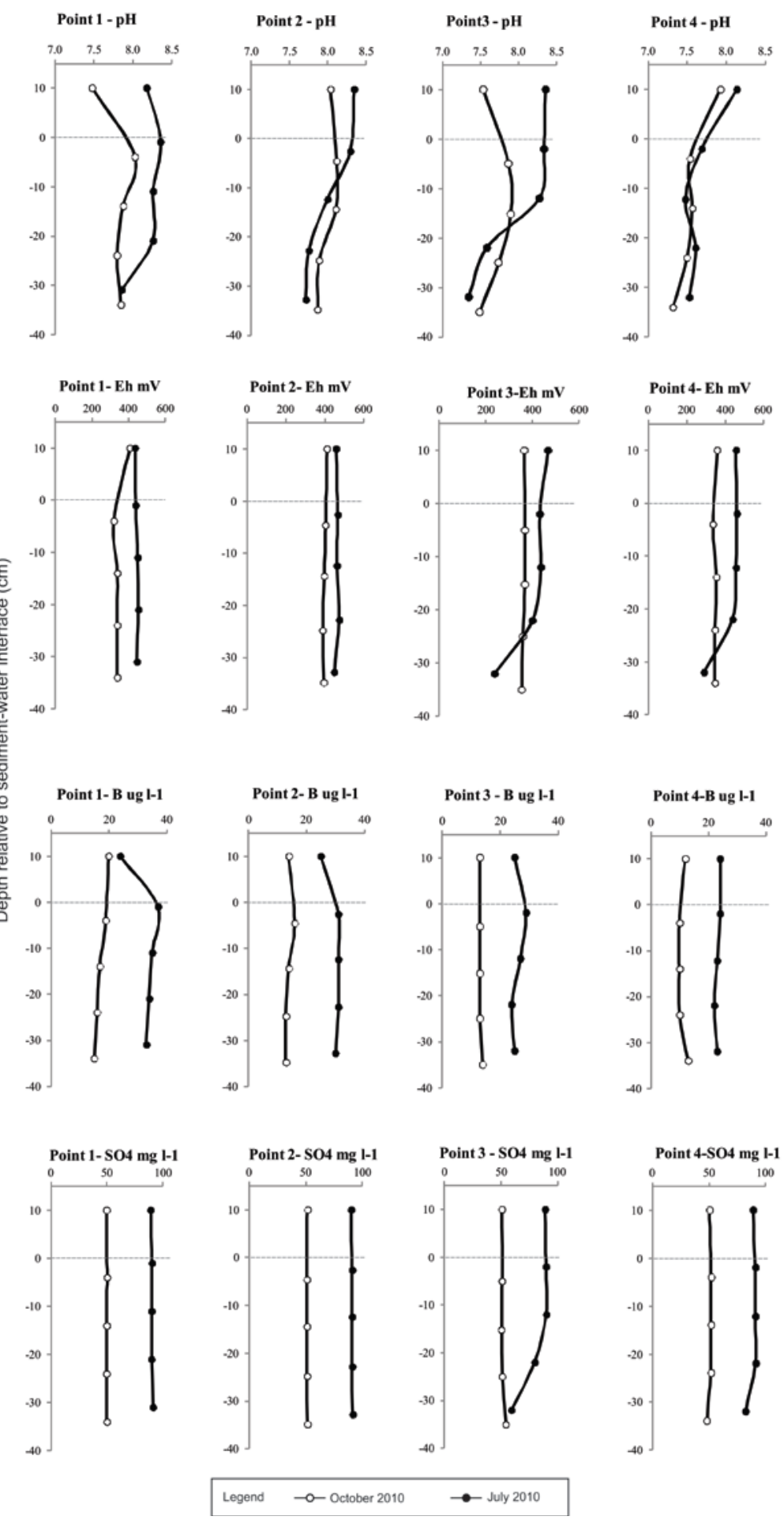

Figure 3 - Depth profiles of pore water $\mathrm{pH}, \mathrm{Eh}, \mathrm{B}$ and $\mathrm{SO}_{4}$ and associated surface water for the sampling points in July 2010 and October 2010. 


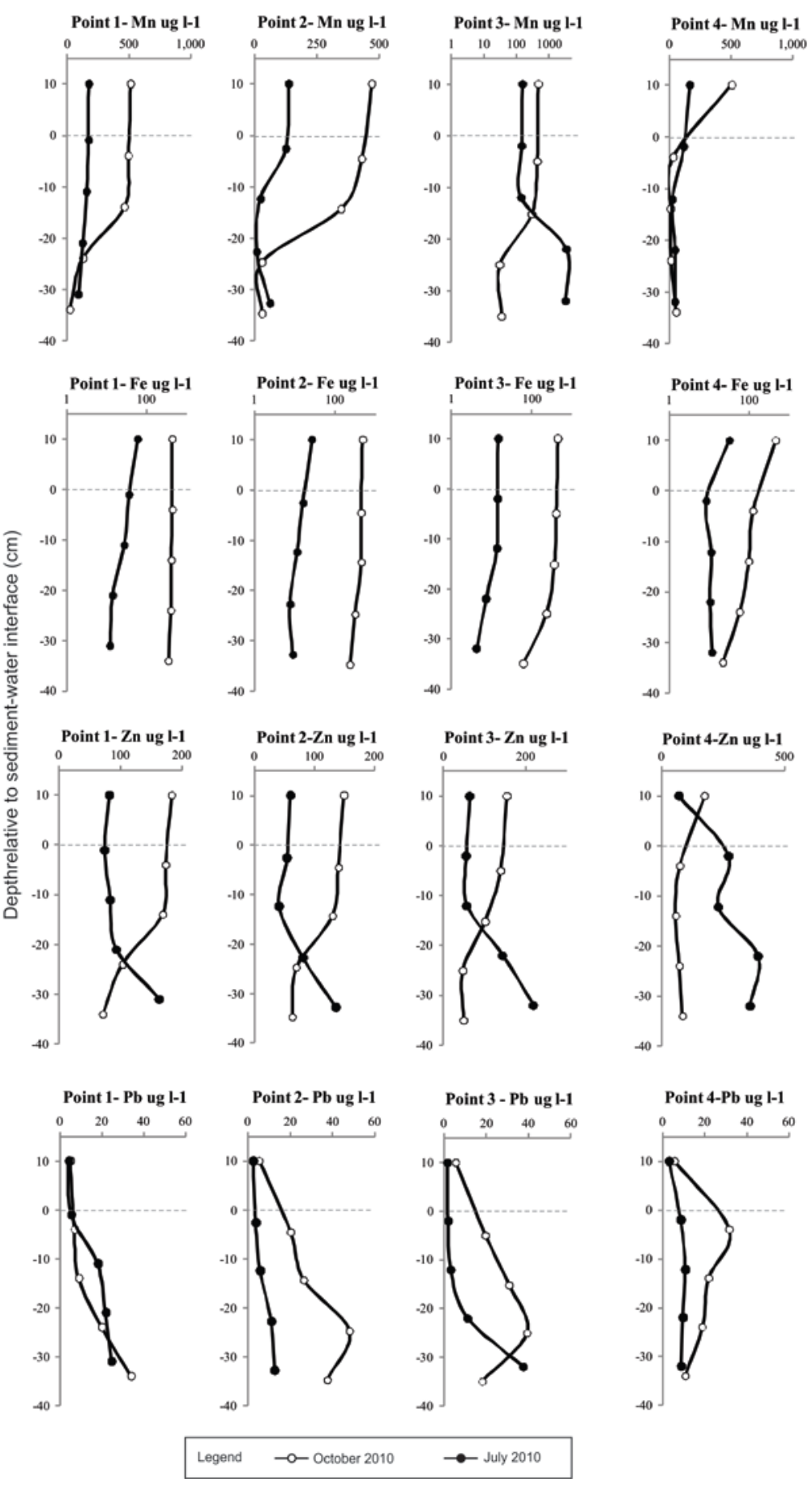

Figure 4 - Depth profiles of pore water $\mathrm{Mn}, \mathrm{Fe}, \mathrm{Zn}$ and $\mathrm{Pb}$ and associated surface water for the sampling points in July 2010 and October 2010. 


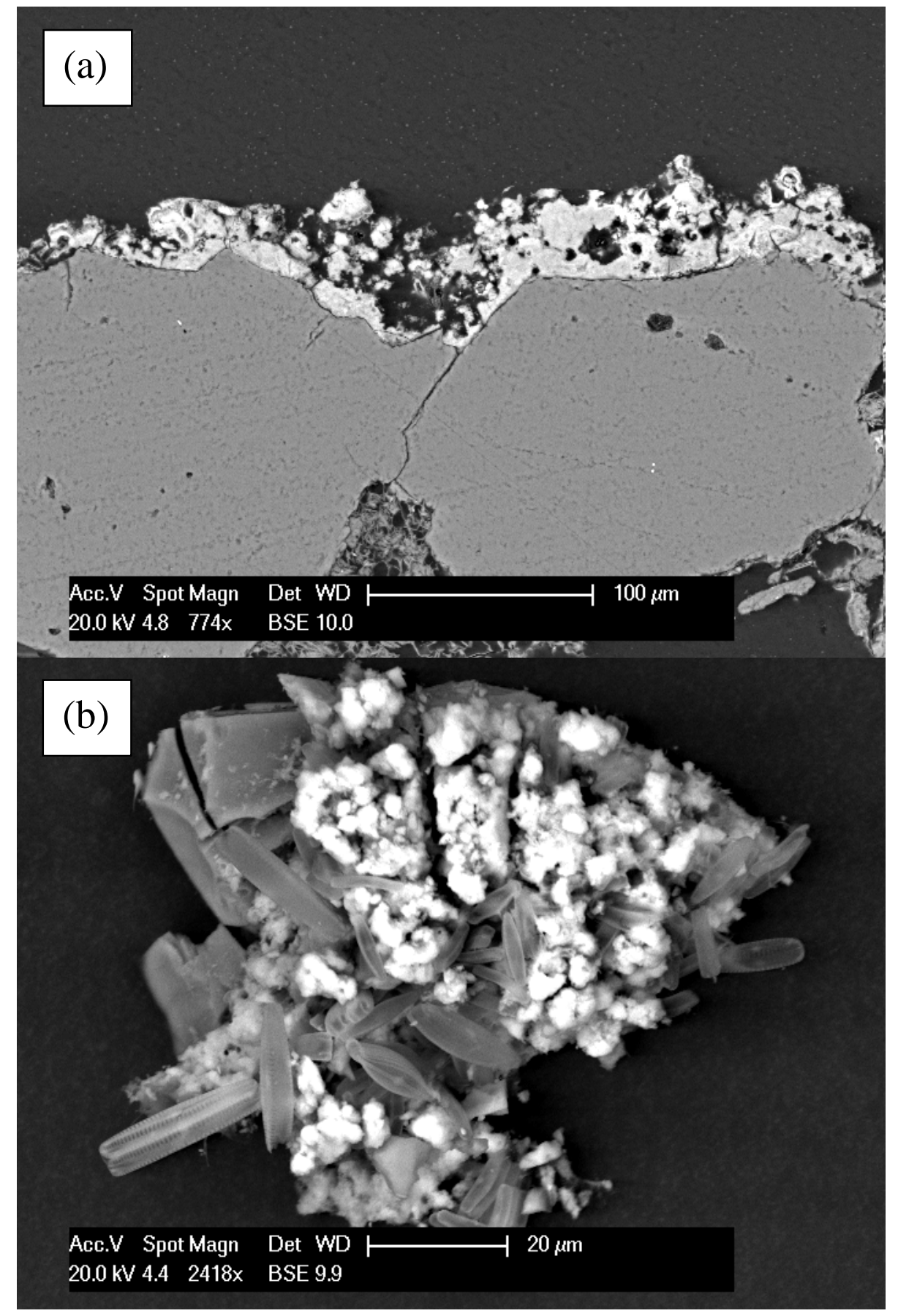

Figure 5 - SEM-BSE images of a) polished section of bed sediment quartz grains (grey) with an authigenic Mn-rich coating (bright); b) details of scraped-off material from the grain coatings showing the assemblage of diatoms (grey) and clusters of Mn-rich particles (bright). 

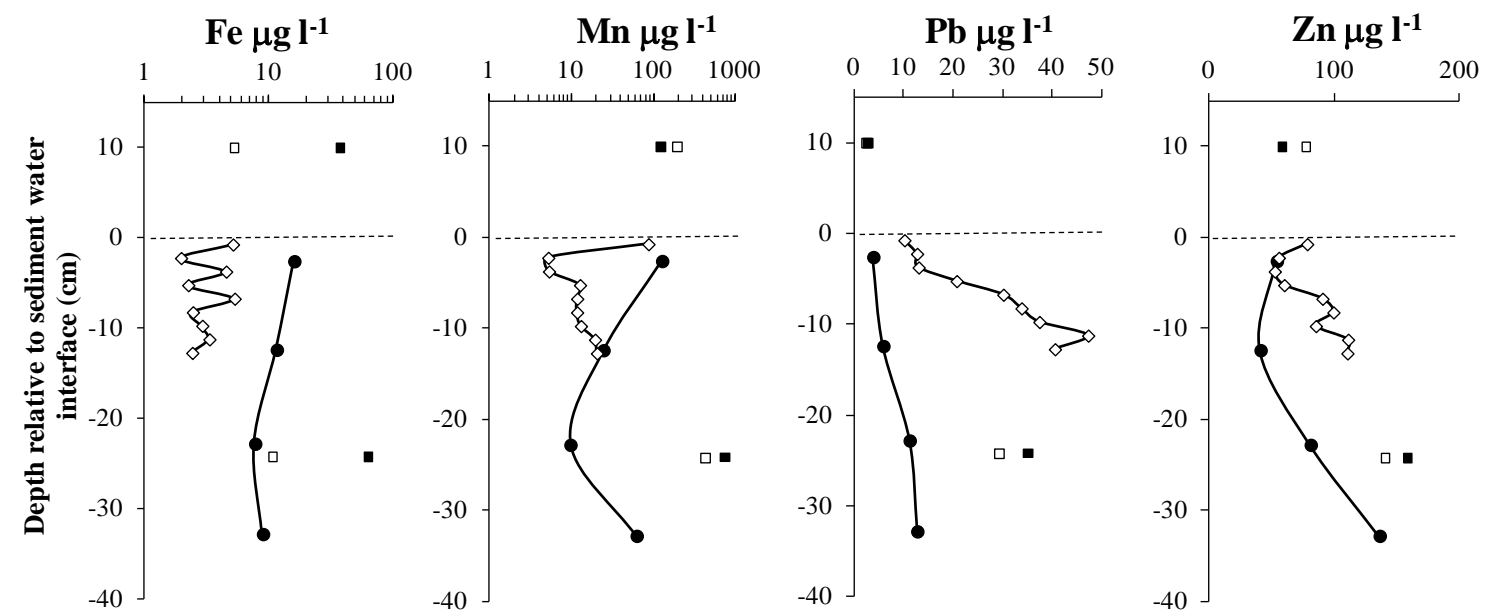

- Grasp sampling $\square$ DGT_piston type

- Multilevel sampler (point 2)

$\diamond$ DGT _sediment probe

Figure 6 - Concentrations of $\mathrm{Fe}, \mathrm{Mn}, \mathrm{Pb}$ and $\mathrm{Zn}$ measured through the DGT sediment probe (at $1.5 \mathrm{~cm}$ resolution) and through multilevel pore water samplers (at $10 \mathrm{~cm}$ resolution) in the sediments of Rookhope Burn in July 2010. Additional measurements obtained with DGT piston type of surface water and pore water are plotted against bulk measurements of respective grasp samples. 

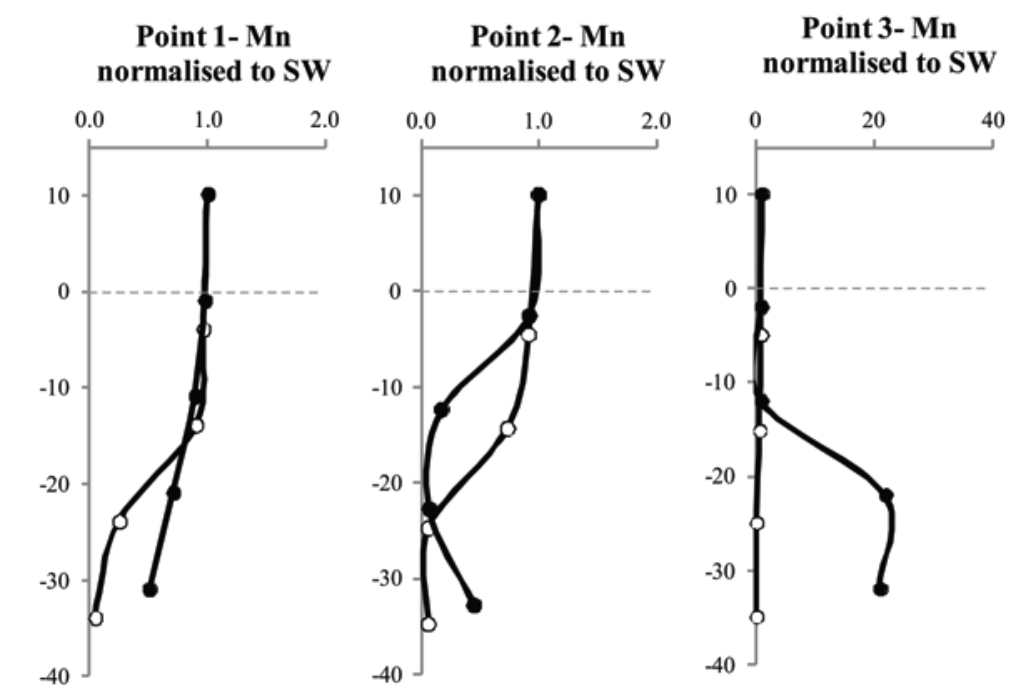

Point 4- Mn normalised to SW

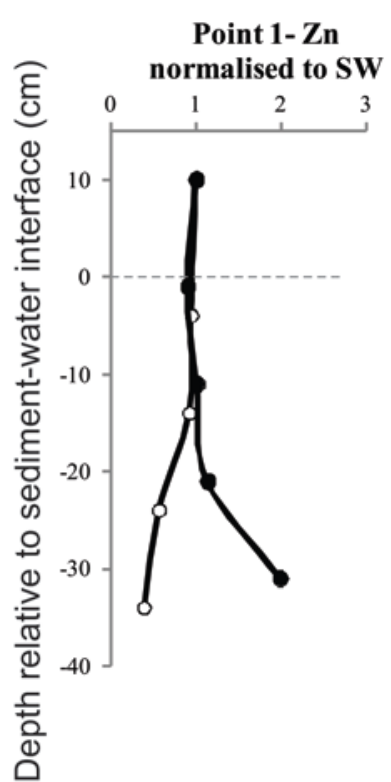

Point 2-Zn

Point 3- Zn

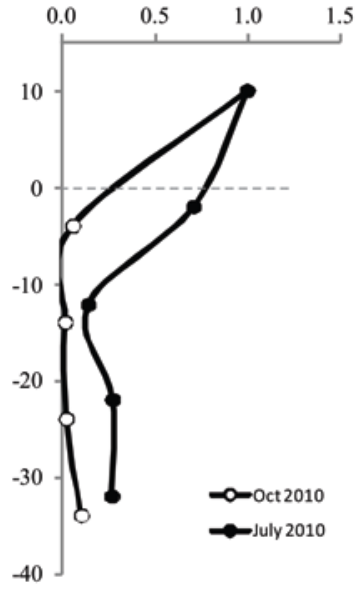

normalised to SW
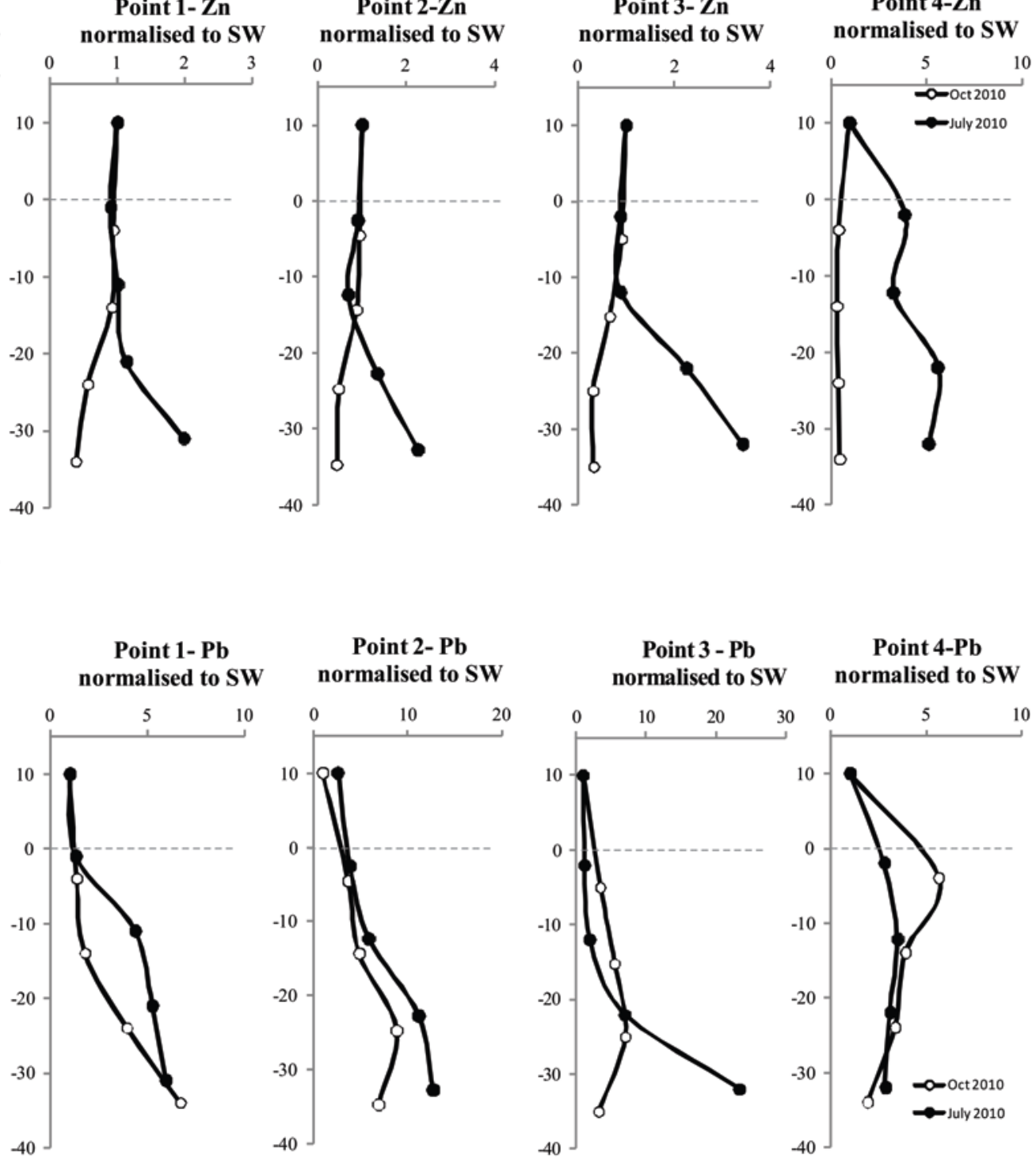

Figure 7- Depth profiles of pore water Mn, Zn and Pb for the sampling points in July 2010 and October 2010 normalised to the respective concentrations in the surface water. 

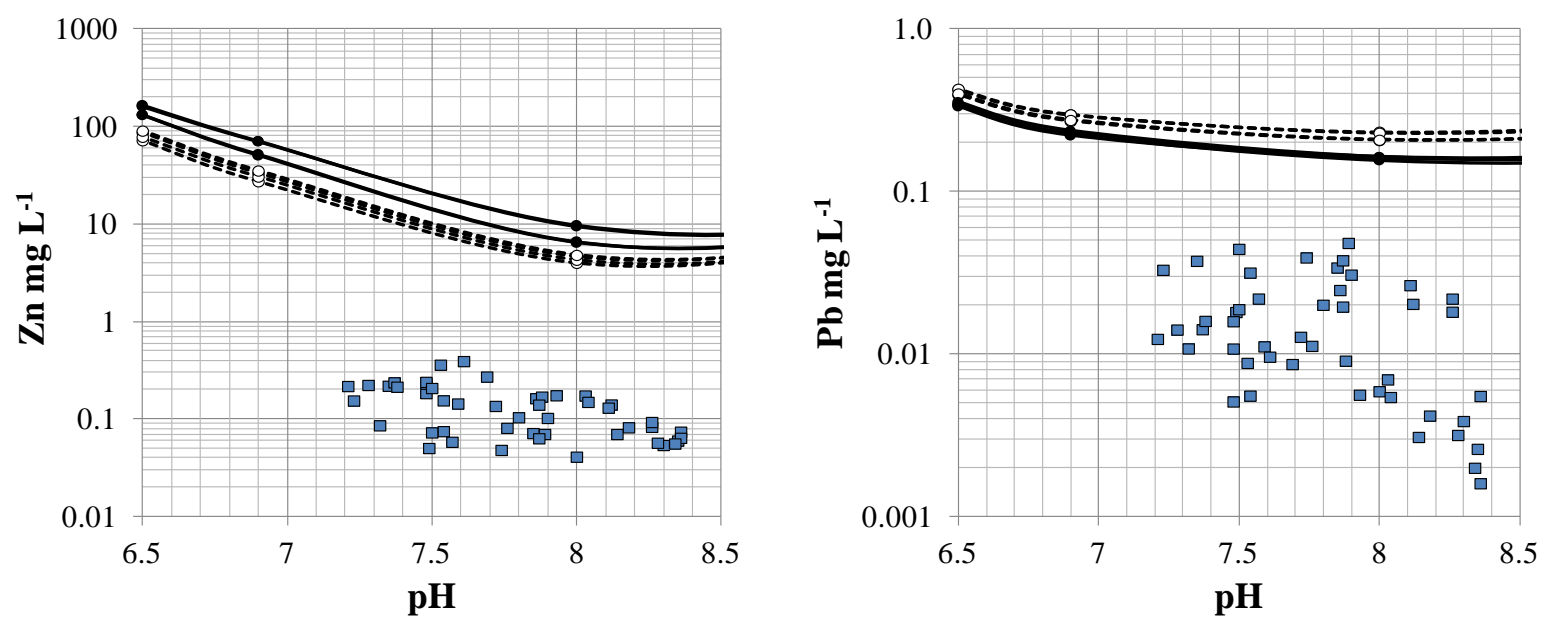

Figure 8 - Modelled aqueous $\mathrm{Pb}$ and $\mathrm{Zn}$ in equilibrium with carbonate minerals cerussite $\mathrm{PbCO}_{3}$ and smithsonite $\mathrm{ZnCO}_{3}$ as a function of $\mathrm{pH}$, computed by batch-reaction calculations using an excess of cerussite and smithsonite $\left(1 \mathrm{~mol} \mathrm{~L}^{-1}\right)$ as the equilibrium phase and the surface water concentrations sampled (dotted lines: July 2010 sampling; full line: October 2010 sampling). Surface water and pore water samples are plotted on the stability diagrams showing undersaturation. 